\title{
RUNOFF, PRECIPITATION, MASS BALANCE, AND ICE VELOCITY MEASUREMENTS AT SOUTH CASCADE GLACIER, WASHINGTON, 1993 BALANCE YEAR
}

By Robert M. Krimmel

U.S. GEOLOGICAL SURVEY

Water-Resources Investigations Report 94-4139

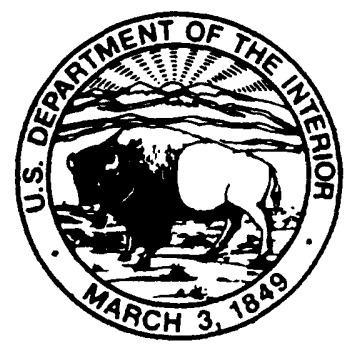




\section{U.S. DEPARTMENT OF THE INTERIOR \\ BRUCE BABBITT, Secretary}

\section{U.S. GEOLOGICAL SURVEY}

Gordon P. Eaton, Director

For additional information write to:

Ice and Climate Project

U.S. Geological Survey

University of Puget Sound

Tacoma, Washington 98416
Copies of this report can

be purchased from:

U.S. Geological Survey

Earth Science Information Center

Open-File Reports Section

Box 25286, MS 517

Denver Federal Center

Denver, Colorado 80225 
Abstract

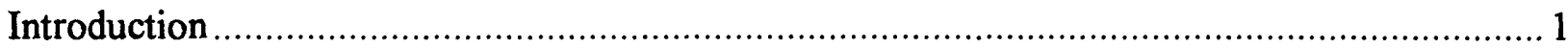

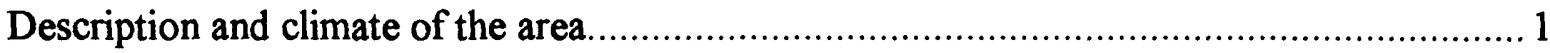

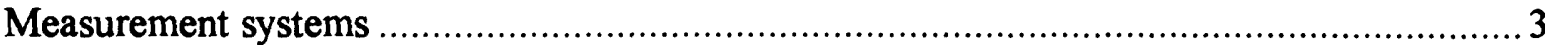

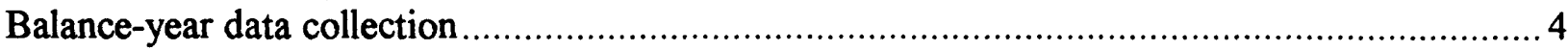

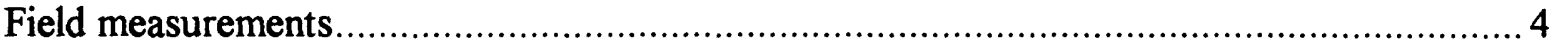

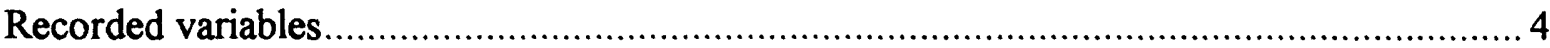

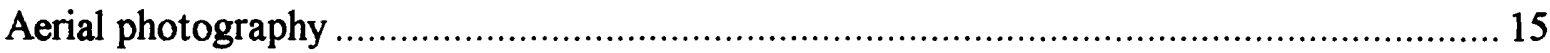

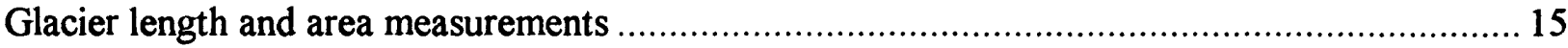

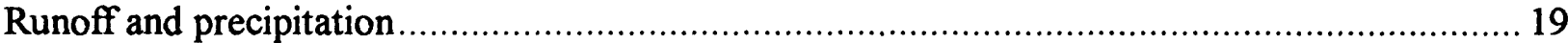

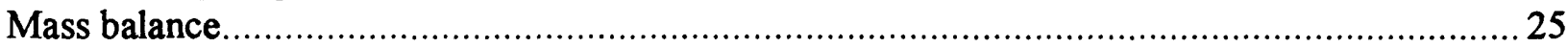

Winter snow balance

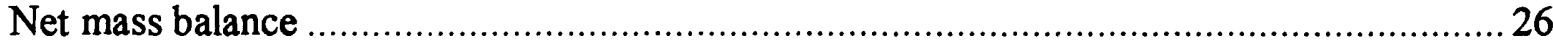

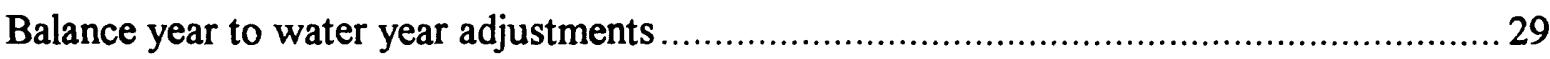

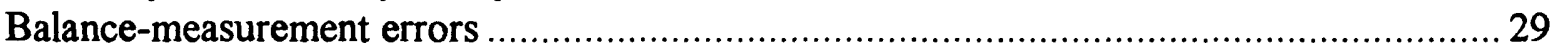

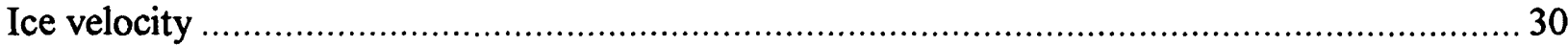

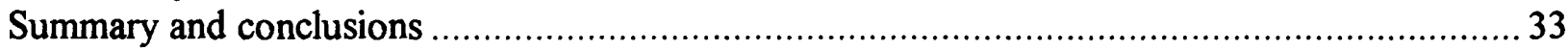

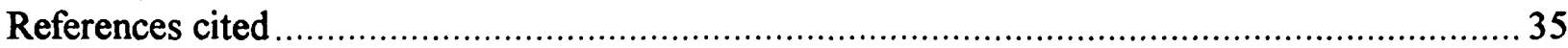

\section{ILLUSTRATIONS}

Figure 1. Map showing South Cascade Glacier and vicinity...............................................

2. Map showing snow depths on South Cascade Glacier, May 5, 1993, as measured by probing

3. Graph showing snow depth and firn or ice loss at South Cascade Glacier at each 1993 stake

4. Chart showing instrumentation at South Cascade Glacier during the 1993 water year......

5. Graph showing barometric pressure, precipitation, and water stage near South Cascade Glacier during the 1993 water year..... 9

6. Graph showing relative humidity and air temperature near South Cascade Glacier during the 1993 water year

7. Graph showing air temperature differences between stations Hut and Ruby, South Cascade Glacier, June-September 1993.

8. Vertical photograph of South Cascade Glacier, September 1, 1993 


\section{ILLUSTRATIONS--Continued}

Page

9. Map showing altitude grid for South Cascade Glacier, measured from stereo vertical photographs taken on September 1, 1993

10. Map showing South Cascade Glacier terminus positions for October 6, 1992 and September 1, 1993 20

11. Graph showing daily runoff from South Cascade Glacier Basin, Middle

Tarn Basin, and Salix Basin, 1993 water year.

12. Graph showing precipitation at Middle Tarn station and runoff from

Salix Basin during July 1993

13. Graph showing South Cascade Glacier snow depth, May 5, 1993, as a function of altitude. 27

14. Graph showing net balance at each South Cascade Glacier 1993 stake 28

15. Map showing surface velocity of South Cascade Glacier in 1957-62 and 1992-93

16. Graph showing winter, summer, and net mass balances for South Cascade Glacier, 1953-93

\section{TABLES}

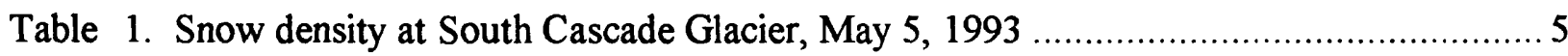

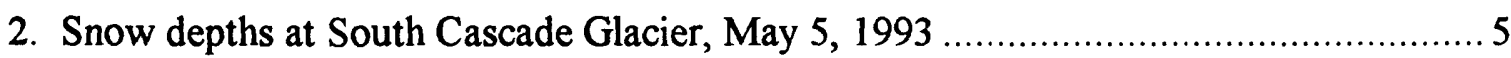

3. Stake measurements at South Cascade Glacier in the 1993 balance year .................... 5

4. Air temperature at 1,615 meters altitude, South Cascade Glacier Basin, 1993 water year

5. Air temperature at 1,867 meters altitude, South Cascade Glacier Basin, 1993 water year.

6. Air temperature at 1,848 meters altitude, South Cascade Glacier Basin, June through September 1993 ......

7. Precipitation at 1,631 meters altitude, South Cascade Glacier Basin, July 1993 13

8. South Cascade Glacier altitude grid, September 1, 1993. 18 


\section{TABLES--Continued}

9. Runoff at South Cascade Glacier Basin, 1993 water year.

10. Runoff at Salix Basin, 1993 water year

11. Discharge measurements in outlet stream of Middle Tarn, near South Cascade Glacier.

12. Runoff at Middle Tam Basin, 1993 water year

13. Positions of velocity features on South Cascade Glacier on

October 6, 1992 and September 1, 1993

\section{CONVERSION FACTORS, VERTICAL DATUM, SYMBOLS, AND MACHINE-READABLE FILES}

\begin{tabular}{lll} 
Multiply & By & To obtain \\
\hline millimeter $(\mathrm{mm})$ & 0.03937 & inch \\
centimeter $(\mathrm{cm})$ & 0.3937 & inch \\
meter $(\mathrm{m})$ & 3.281 & foot \\
kilometer $(\mathrm{km})$ & 0.6214 & mile \\
square kilometer $\left(\mathrm{km}^{2}\right)$ & 0.3861 & square mile \\
cubic meter per second $\left(\mathrm{m}^{3} / \mathrm{s}\right)$ & 35.31 & cubic foot per second \\
gram $(\mathrm{g})$ & 0.002205 & pound \\
kilopascal $(\mathrm{kPa})$ & 0.1450 & pound per square inch \\
degree Celsius $\left({ }^{\circ} \mathrm{C}\right)$ & 1.8, then add 32 & degrees Fahrenheit
\end{tabular}

\section{Vertical datum:}

In this report "sea level" refers to the National Geodetic Vertical Datum of 1929 (NGVD of 1929)--a geodetic datum derived from a general adjustment of the first-order level nets of both the United States and Canada, formerly called Sea Level Datum of 1929. 
Symbols used in this report:

$\bar{b}_{0}$

The change in balance between the minimum balance near the beginning of the water year and October 1.

$\bar{b}_{1}$ The change in balance between the minimum balance near the end of the water year and September 30.

$\bar{b}_{\mathrm{a}}$ The change in snow, firn, and ice storage between the beginning and end of

$\bar{b}_{\mathrm{m}}(\mathrm{s})$ some fixed period, which here is the water year.

$\bar{b}_{\mathrm{n}}$ The snow above the previously formed summer surface as measured directly by field work in late spring as near as possible to the time of greatest glacier mass.

$\bar{b}_{\mathrm{w}}(\mathrm{s})$ The change in snow, firn, and ice storage between times of minimum mass.

$t_{0}^{\prime}$ The maximum of snow mass during the balance year.

The time at which the glacier mass is at a minimum at the beginning of the balance year.

$t_{1}$ The time at which the glacier mass is at a minimum at the end of the balance year.

\section{Machine-readable files:}

Most of the data contained in this report have been recorded on easily copied computer media. This machine-readable material is available from the World Data Center, Campus Box 449, University of Colorado, Boulder, CO 80309. 


\title{
RUNOFF, PRECIPITATION, MASS BALANCE, AND ICE VELOCITY MEASUREMENTS
}

AT SOUTH CASCADE GLACIER, WASHINGTON, 1993 BALANCE YEAR

\author{
Robert M. Krimmel
}

\begin{abstract}
Winter snow accumulation and summer snow, firn, and ice ablation were measured at South Cascade Glacier, Wash., to determine the winter mass balance and net mass balance for the 1993 balance year. The 1993 winter mass balance, averaged over the glacier, was 1.98 meters, and the net mass balance was -1.23 meters. This negative balance continued a trend of negative balance years beginning in 1977. Air temperature, barometric pressure, and runoff from this glacier basin and an adjacent non-glacierized basin also were continuously measured. Surface ice velocity was measured over a 1-year period. This report makes all these data available to users throughout the glaciological and climatological community.
\end{abstract}

\section{INTRODUCTION}

South Cascade Glacier is a small valley glacier near the crest of the North Cascade Range, Washington State (fig. 1). Numerous variables relating to the glacier regime have been measured on and near South Cascade Glacier since the late 1950's. The long-term goal of this project is to understand the climate-glacier relation. A short-term goal is to document the measurements with sufficient precision so that an internally consistent record of conditions on and around the glacier can be assembled despite personnel changes, discontinuous records, and changing methods of data collection and analysis. Some periods of record at South Cascade Glacier have been documented. Work from 1957-64 is described by Meier and Tangborn (1965), work from 1965-67 is described by Meier and others (1971) and by Tangborn and others (1977). Mass balance results for 1958-85 are summarized by Krimmel (1989), and are presented in detail for 1992 (Krimmel, 1993). The purpose of this report is to document the measurements of the 1993 balance year that are relevant to the relation between South Cascade Glacier and climate. These measurements include those of basin runoff, precipitation, air temperature, snow thickness, density and distribution, ice ablation, surface altitude, and velocity.

\section{Description and Climate of the Area}

South Cascade Glacier is located at the head of the South Fork of the Cascade River, a tributary to the Skagit River, which flows into Puget Sound about $100 \mathrm{~km}$ to the west. The region is dominated by steep terrain, with relief of more than $1,000 \mathrm{~m}$. Areas within the basin not covered by glacier ice or water are underlain by bedrock. The bedrock is mantled either by a thin layer of soil and, in places, by scrub conifer, heather, or other vegetation typical of the high North Cascade Range, or is covered by glacial moraine or outwash material. 


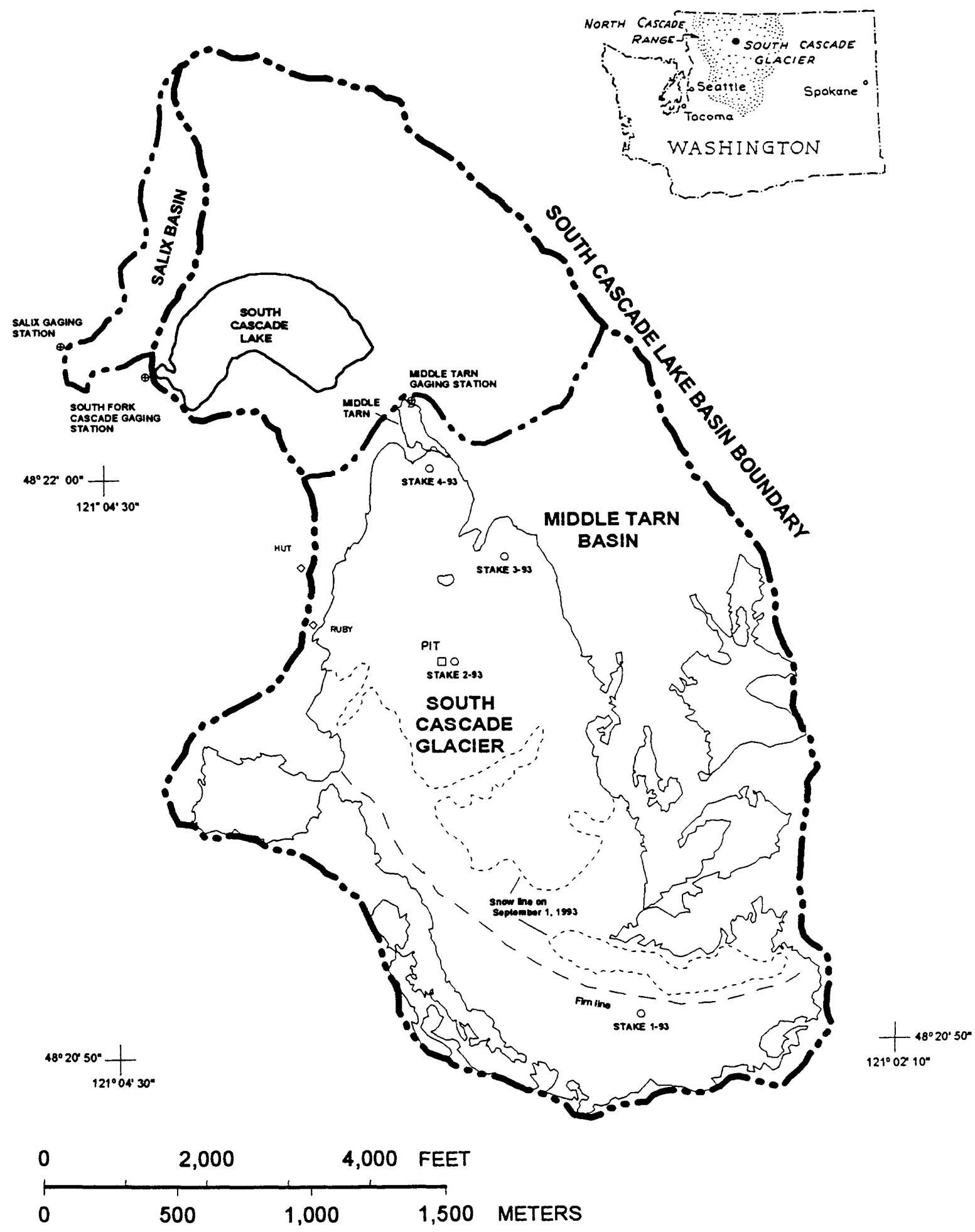

FIGURE 1. South Cascade Glacier and vicinity. 
South Cascade Lake Basin has an area of ${ }^{1} 6.14 \mathrm{~km}^{2}$, and spans from 1,615 to $2,518 \mathrm{~m}$ altitude. A sub-basin of the South Cascade Lake Basin is the 4.46- $\mathrm{km}^{2}$ Middle Tarn Basin ${ }^{2}$, which constitutes the southern two-thirds of the South Cascade Lake Basin. Virtually all icemelt $^{3}$ within the South Cascade Lake Basin takes place in the Middle Tarn Basin. Near the end of the 1993 melt season, the total snow- and ice-covered area in Middle Tarn Basin was $2.51 \mathrm{~km}^{2}$.

Salix Basin is an unglacierized basin adjacent to the South Cascade Lake Basin. It has an area of ${ }^{4} 0.22 \mathrm{~km}^{2}$, spans from 1,587 to $2,140 \mathrm{~m}$ altitude, and is predominantly south facing.

The climate of the region is maritime. Near the glacier, typical winter low temperatures are about $-10^{\circ} \mathrm{C}$, and typical summer high temperatures are about $20^{\circ} \mathrm{C}$. Most of the precipitation, which commonly reaches $4.5 \mathrm{~m}$ annually (Meier and others, 1971), falls as snow in the period October to May.

\section{Measurement Systems}

Glacier mass balance definitions (Mayo and others, 1972) are adhered to in this report, and the stratigraphic system, which is more field compatible than the fixed date system, is usually used. The specific terms are defined when used. There are other mass balance nomenclatures in use, notably those described by Østrem and Brugman (1991), which could as well be used to report these results. The definitions by Mayo and others (1972) are used to maintain consistency with earlier reports on South Cascade Glacier work.

The balance year, defined by Mayo and others (1972) as the interval between the minimum glacier mass in one year and the minimum glacier mass the following year, is used when appropriate. The water year is the interval between the beginning of October and the end of the following September; it is designated by the calendar year in which it ends.

All local coordinates are in meters, in which the local $+Y$ axis is approximately true north. Vertical location is in meters above the National Geodetic Datum of 1929. Horizontal locations are defined by a local system that can be converted to Universal Transverse Mercator (UTM) zone 10 coordinates by:

$$
\begin{aligned}
& \text { UTM easting }=\text { local } X(0.99985)+642,000 \\
& \text { UTM northing }=\text { local } Y(0.99985)+5,355,000 .
\end{aligned}
$$

Densities are given as a decimal fraction of the density of water, the density of which is considered to be 1,000 kilograms per cubic meter.

1 The area of this basin has been previously reported as 6.02 and $6.11 \mathrm{~km}^{2}$. These differences are due to different interpretations of the drainage divide.

2 "Middle Tarn" is an unofficial name.

${ }^{3}$ A small, debris-covered area of perennial ice lies outside of the Middle Tarn Basin.

${ }^{4}$ Salix Basin drainage divides are poorly defined. 


\section{BALANCE-YEAR DATA COLLECTION}

\section{Field Measurements}

Several visits are made each year to the South Cascade Glacier Basin to accomplish data collection that is impractical by remote or automated methods, and to maintain instruments and facilities.

The first visit of the 1993 balance year was on January 31, 1993, at which time snow thickness and level at stake 4-1992 (Krimmel, 1993) were measured to help determine the 1992 final balance increment, which is also the 1993 initial balance increment (Mayo and others, 1972). Measurements to determine the 1993 measured winter snow balance $\left[\bar{b}_{\mathrm{m}}(\mathrm{s})\right]$ were made on May $5-6,1993$ at which time snow density (table 1, fig. 1 for pit location) and snow depth (table 2, fig. 2) were measured. Stakes (fig. 1) were set in holes drilled entirely through the snow so that the rate of snow melt could be determined on subsequent visits as indicated in table 3 and figure 3. The final visit of the 1993 balance year was on October 20, 1993, after which there was minor snow and ice melt.

\section{Recorded Variables}

Several variables are measured continuously: these are truncated to the water year (WY), October 1, 1992 through September 30, 1993. When information beyond the WY concerning these variables is required for analysis of the glacier mass balance, the required data are discussed. The continuous measurements may be stored on analog recorders, which give a continuous trace of the variable; on digital recorders, which store instantaneous data at regular time intervals; or transmitted via satellite through a data collection platform (DCP) to Tacoma. The time interval may be different for different variables. Some variables are stored on redundant analog and digital recorders. The periods for which each variable was measured are shown in figure 4 , the values of these variables are shown graphically in figures 5 and 6 , and numerical summaries of daily values of some of these variables are given in tables 4-7.

River stage, air temperature, and barometric pressure values are relayed from the South Fork Cascade River gaging station (fig. 1) to Tacoma, Wash., through the DCP. The DCP temperature is sampled once each hour. An analog strip-chart recorder also records air temperature, serving as a back-up system. Separate sensors are housed in separate radiation shields $6 \mathrm{~m}$ above ground level. During January 1993, when the DCP was not working, data were obtained from the strip chart, which was calibrated using prior data from the DCP.

Air temperature is also sampled and recorded once each hour on a data logger at $1,867 \mathrm{~m}$ altitude at RUBY (fig. 1). This sensor is housed in a radiation shield $1.5 \mathrm{~m}$ above the ground. Wind scour keeps the winter snow from burying this sensor. Air temperature data at both sites are estimated to be accurate to $1^{\circ} \mathrm{C}$. Beginning in June 1993, air temperature and relative humidity were measured at the Hut (fig. 1) and transmitted to Tacoma via a DCP. The Hut and Ruby air temperature sensors are separated by $19 \mathrm{~m}$ vertically and $278 \mathrm{~m}$ horizontally. A graphical comparison of these data (fig. 7) shows that systematic diurnal differences occur, but daily and longer period averages are nearly the same from both sensors. 
TABLE 1. Snow density at South Cascade Glacier, May 5, 1993

[Measured in a snow pit, through the entire thickness of the snow, at local $X=1888$, $\mathrm{Y}=2951, \mathrm{Z}=1844$ meters]

\begin{tabular}{crrr}
$\begin{array}{c}\text { Sample } \\
\text { bottom } \\
\text { depth } \\
\text { entimeters) }\end{array}$ & $\begin{array}{c}\text { Sample } \\
\text { length } \\
\text { (centimeters) }\end{array}$ & $\begin{array}{c}\text { Mass } \\
\text { (grams) }\end{array}$ & Density \\
\hline 49 & 49 & 735 & 0.37 \\
98 & 49 & 710 & 0.35 \\
145 & 47 & 730 & 0.38 \\
197 & 52 & 930 & 0.44 \\
Begin using coring auger & & & \\
274 & 77 & 1,810 & 0.51 \\
340 & 66 & 1,420 & 0.47 \\
372 & 32 & 685 & 0.47 \\
400 & 25 & 590 & 0.52 \\
455 & 55 & 1,160 & 0.46 \\
490 & 33 & 770 & 0.51 \\
519 & 28 & 590 & 0.46 \\
\hline
\end{tabular}

TABLE 2. Snow depths at South

Cascade Glacier, May 5, 1993

[Depths; in meters (m) measured with a probe rod; $\mathrm{X}, \mathrm{Y}$, and $\mathrm{Z}$ are local coordinates, \pm 100 meters]

\begin{tabular}{rrrrrrrrr}
\hline$X$ & $Y$ & $Z$ & $\begin{array}{c}\text { Snow } \\
\text { depth } \\
(\mathrm{m})\end{array}$ & $\mathrm{X}$ & $\mathrm{Y}$ & $\mathrm{Z}$ & $\begin{array}{c}\text { Snow } \\
\text { depth } \\
(\mathrm{m})\end{array}$ \\
\hline 0 & 0 & 1618 & 2.0 & 1938 & 2781 & 1848 & 4.7 \\
2670 & 1590 & 2048 & 5.6 & 1913 & 2838 & 1847 & 4.8 \\
2618 & 1648 & 2036 & 5.6 & 1950 & 2936 & 1844 & 5.3 \\
2570 & 1710 & 2034 & 5.6 & 1993 & 2972 & 1842 & 5.6 \\
2517 & 1754 & 2032 & 4.9 & 2046 & 2997 & 1841 & 5.8 \\
2463 & 1805 & 2010 & 4.9 & 2104 & 3030 & 1835 & 3.6 \\
2424 & 1858 & 1993 & 6.4 & 2146 & 3066 & 1830 & 4.1 \\
2381 & 1922 & 1962 & 5.3 & 2206 & 3117 & 1810 & 2.8 \\
2348 & 1977 & 1953 & 5.0 & 2246 & 3161 & 1773 & 3.1 \\
2304 & 2039 & 1952 & 4.4 & 2217 & 3203 & 1760 & 3.1 \\
2269 & 2095 & 1952 & 4.3 & 2171 & 3254 & 1742 & 3.1 \\
2236 & 2149 & 1945 & 4.3 & 2128 & 3295 & 1740 & 2.5 \\
2210 & 2217 & 1936 & 4.4 & 2070 & 3347 & 1740 & 5.0 \\
2174 & 2296 & 1925 & 4.3 & 2005 & 3333 & 1745 & 2.9 \\
2142 & 2361 & 1915 & 4.3 & 1906 & 3338 & 1730 & 2.5 \\
2118 & 2422 & 1896 & 5.4 & 1845 & 3394 & 1700 & 3.5 \\
2077 & 2491 & 1880 & 4.8 & 1820 & 3468 & 1690 & 2.8 \\
2049 & 2552 & 1867 & 4.9 & 1815 & 3533 & 1670 & 1.7 \\
2021 & 2613 & 1855 & 4.8 & 1808 & 3620 & 1650 & 1.6 \\
1989 & 2672 & 1850 & 4.6 & 1798 & 3656 & 1645 & 1.1 \\
1957 & 2733 & 1849 & 4.8 & & & & \\
\hline
\end{tabular}

TABLE 3. Stake measurements at South Cascade Glacier in the 1993 balance year

[Surface material may be snow (s), firn (f), or ice (i); density estimated based on interpolation between measurements made in early May, and assumed density of firn of 0.6 . Balance is the gain or loss of material, referenced to the previous year's melt horizon, in water content. Local X, Y, and $\mathrm{Z}$ coordinates (in meters) given for each stake]

\begin{tabular}{|c|c|c|c|c|}
\hline Date & $\begin{array}{l}\text { Surface } \\
\text { material }\end{array}$ & $\begin{array}{c}\text { Depth } \\
\text { (meters) }\end{array}$ & Density & $\begin{array}{l}\text { Balance } \\
\text { (meters) }\end{array}$ \\
\hline \multicolumn{5}{|c|}{$[X=2575, Y=1632, Z=2045$} \\
\hline May 5 & $\mathbf{s}$ & 5.45 & 0.41 & 2.23 \\
\hline Aug. 18 & $\mathbf{s}$ & 1.17 & .53 & 0.62 \\
\hline Sept. 7 & $\mathbf{s}$ & .57 & .55 & .31 \\
\hline Oct. 12 & $\mathbf{s}$ & .21 & .58 & .12 \\
\hline \multicolumn{5}{|c|}{$[X=1888, Y=2951, Z=1844]$} \\
\hline May 5 & $\mathbf{s}$ & 4.7 & 0.45 & 2.12 \\
\hline June 30 & $\mathbf{s}$ & 2.18 & .48 & 1.05 \\
\hline Aug. 18 & $\mathbf{s} / \mathbf{f}$ & 0.01 & .53 & - \\
\hline Sept. 7 & $\mathrm{i}$ & -0.74 & .9 & -0.67 \\
\hline Oct. 12 & $i$ & -1.29 & .9 & -1.16 \\
\hline
\end{tabular}

\begin{tabular}{|c|c|c|c|c|}
\hline Date & $\begin{array}{l}\text { Surface } \\
\text { material }\end{array}$ & $\begin{array}{c}\text { Depth } \\
\text { (meters) }\end{array}$ & Density & $\begin{array}{l}\text { Balance } \\
\text { (meters) }\end{array}$ \\
\hline \multicolumn{5}{|c|}{ Stake 3-93 $[X=2075, Y=3341, Z=1735]$} \\
\hline May 5 & $\mathrm{~s}$ & 5.0 & 0.47 & 2.35 \\
\hline June 30 & $\mathbf{s}$ & 2.0 & .48 & 0.96 \\
\hline Aug. 18 & $\mathrm{i}$ & -0.72 & .9 & -0.65 \\
\hline Sept. 7 & $\mathbf{i}$ & -1.7 & .9 & -1.53 \\
\hline Oat. 12 & i & -2.39 & 9 & -2.15 \\
\hline \multicolumn{5}{|c|}{ Stake 4-93 $[X=1799, Y=3672, Z=1651]$} \\
\hline May 5 & s & 1.1 & 0.49 & 0.54 \\
\hline June 1 & $\mathrm{i}$ & -0.94 & .9 & -0.85 \\
\hline June 30 & $\mathrm{i}$ & -2.24 & .9 & -2.02 \\
\hline Aug. 18 & $\mathrm{i}$ & -4.82 & 9 & -4.34 \\
\hline Sept. 7 & $\mathrm{i}$ & -6.01 & .9 & -5.41 \\
\hline Oct. 12 & $\mathrm{i}$ & -7.18 & .9 & -6.46 \\
\hline
\end{tabular}




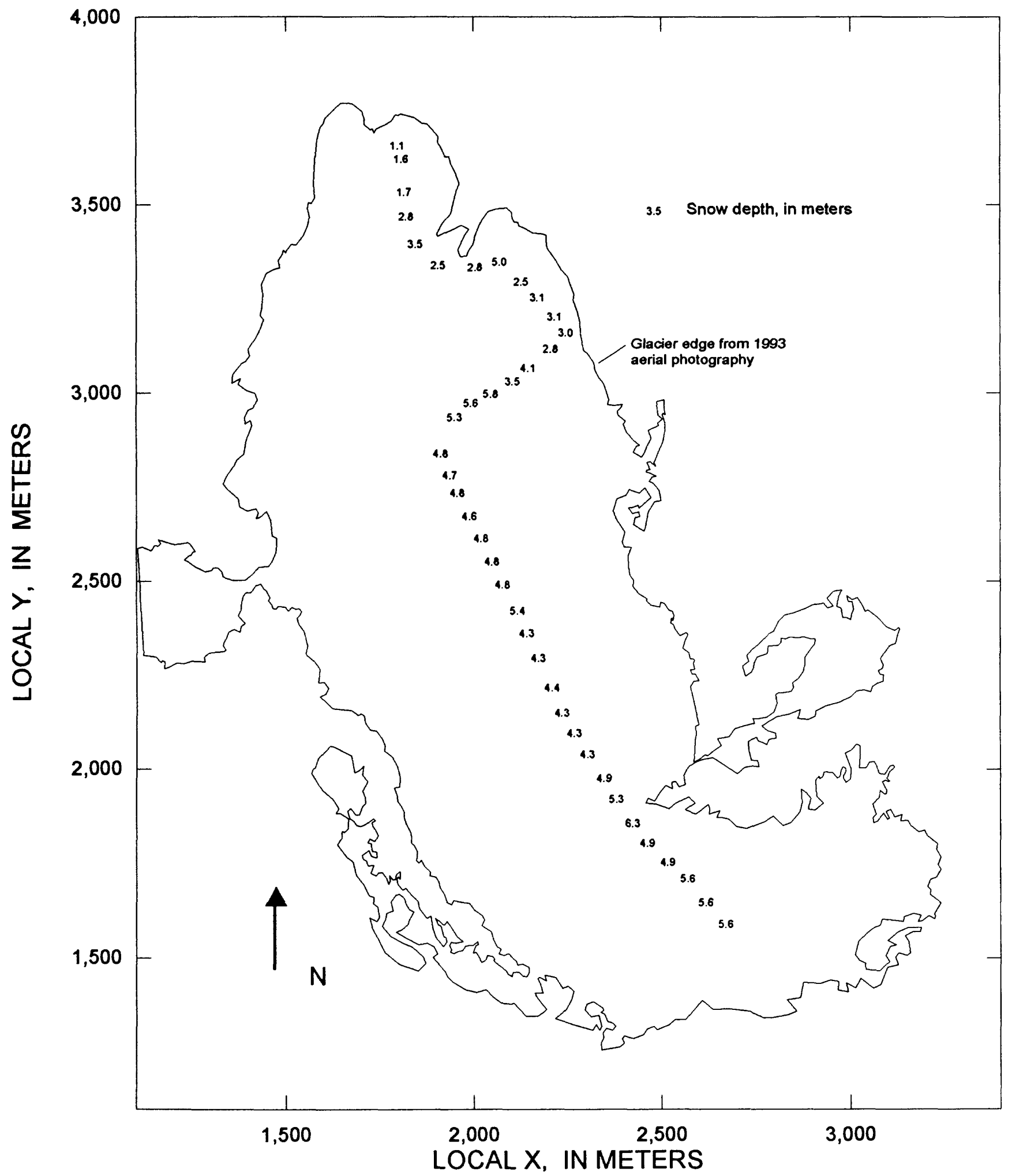

FIGURE 2. Snow depths on South Cascade Glacier, May 5, 1993, as measured by probing. The locations were estimated in the field by pacing, and estimated to be accurate to 100 meters. The probe depths are accurate to 0.1 meter. 


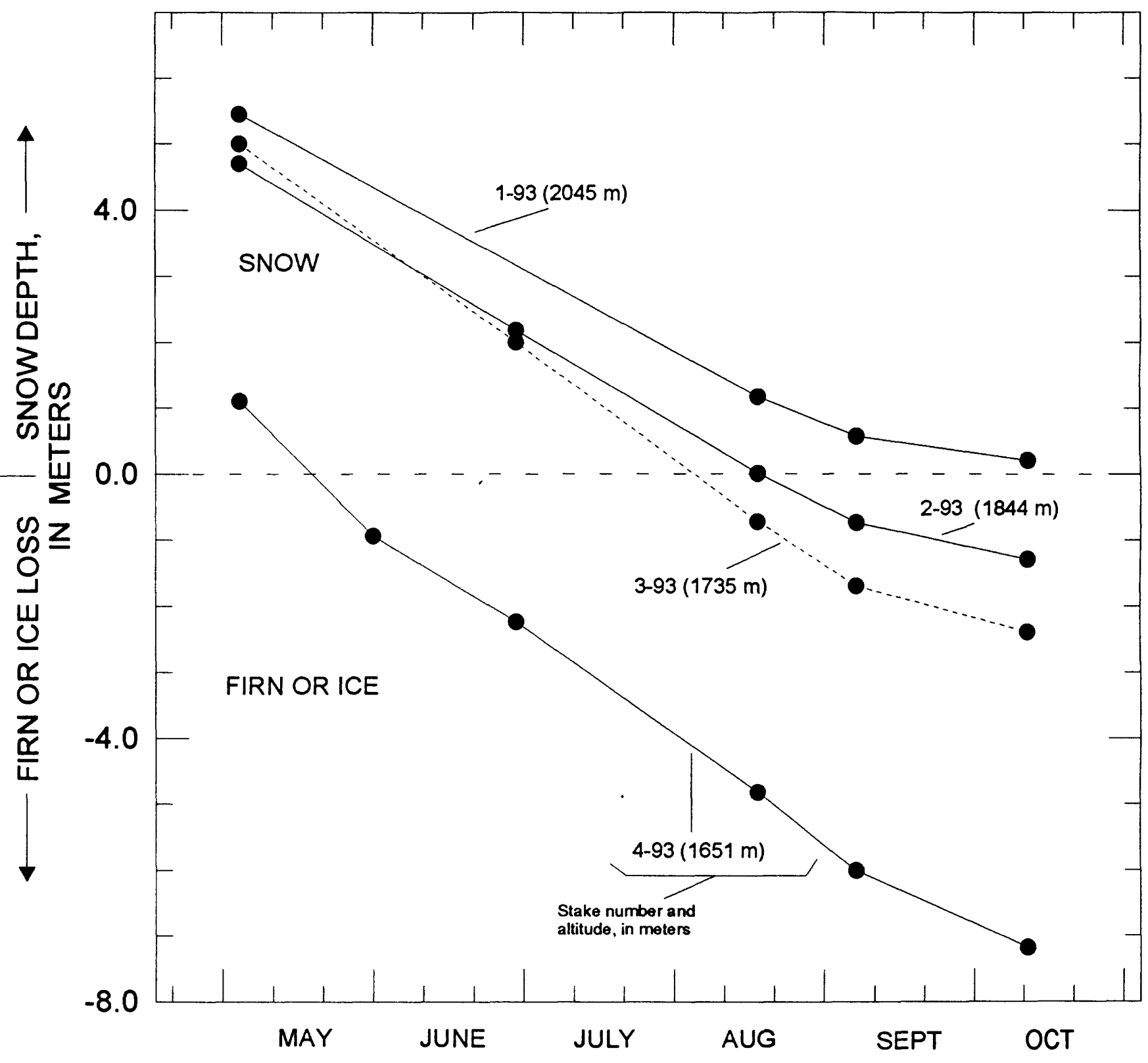

FIGURE 3. Snow depth and firn or ice loss at South Cascade Glacier at each 1993 stake. Depths are accurate to 0.1 meter. (Stake locations shown on figure 1.) 
Salix Creok stage

South Fork Cascade River stage

1615 meter air temperature

1615 meter barometric pressure

Middle Tarn stage

1631 meter precipitation

1848 meter air temperature

1848 meter relative humidity

1867 meter air temperature

Stake measurement

Site visits for mass balance

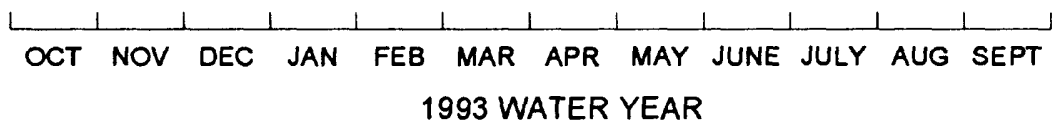

FIGURE 4. Instrumentation at South Cascade Glacier during the 1993 water year. 

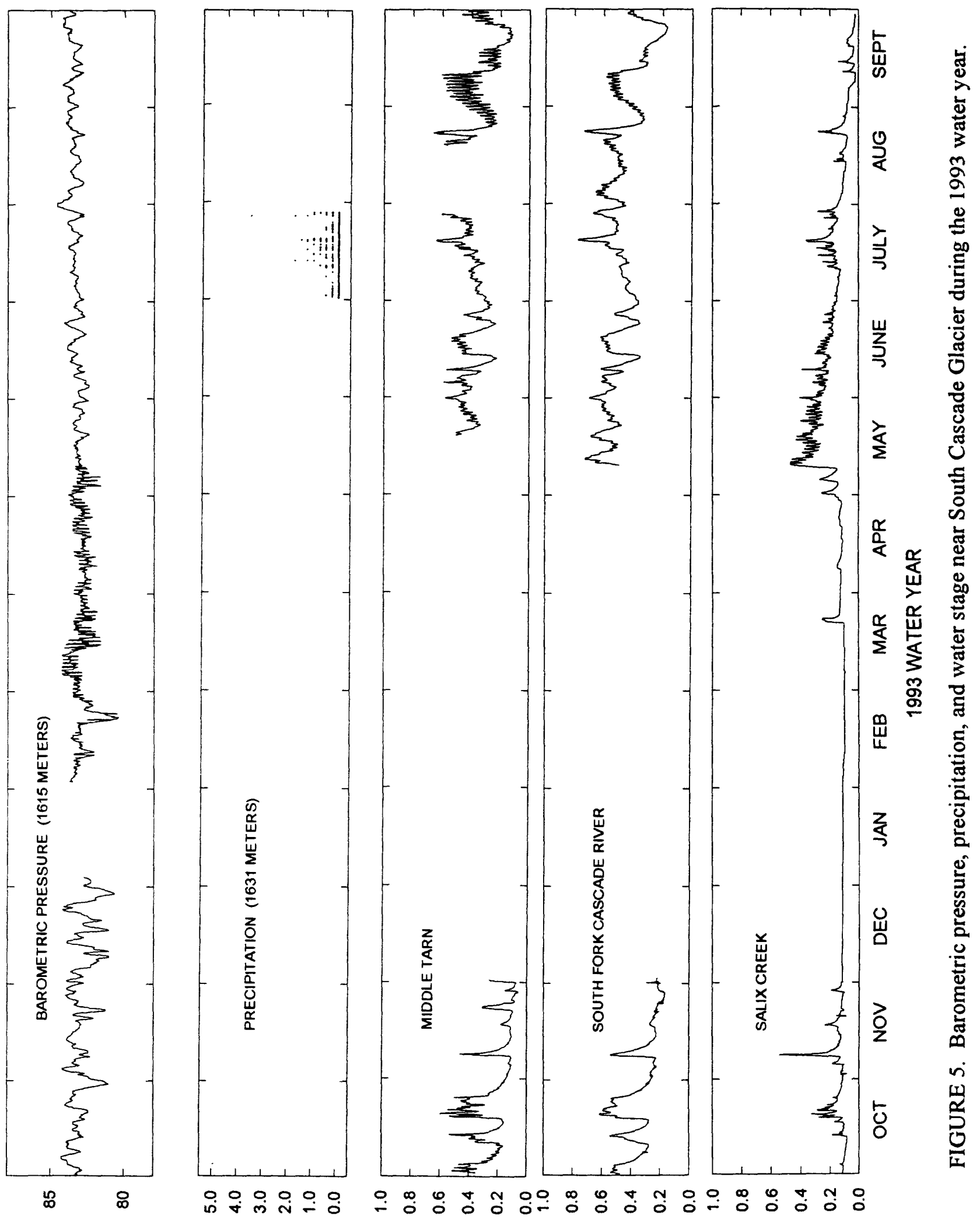

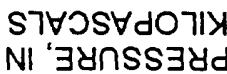



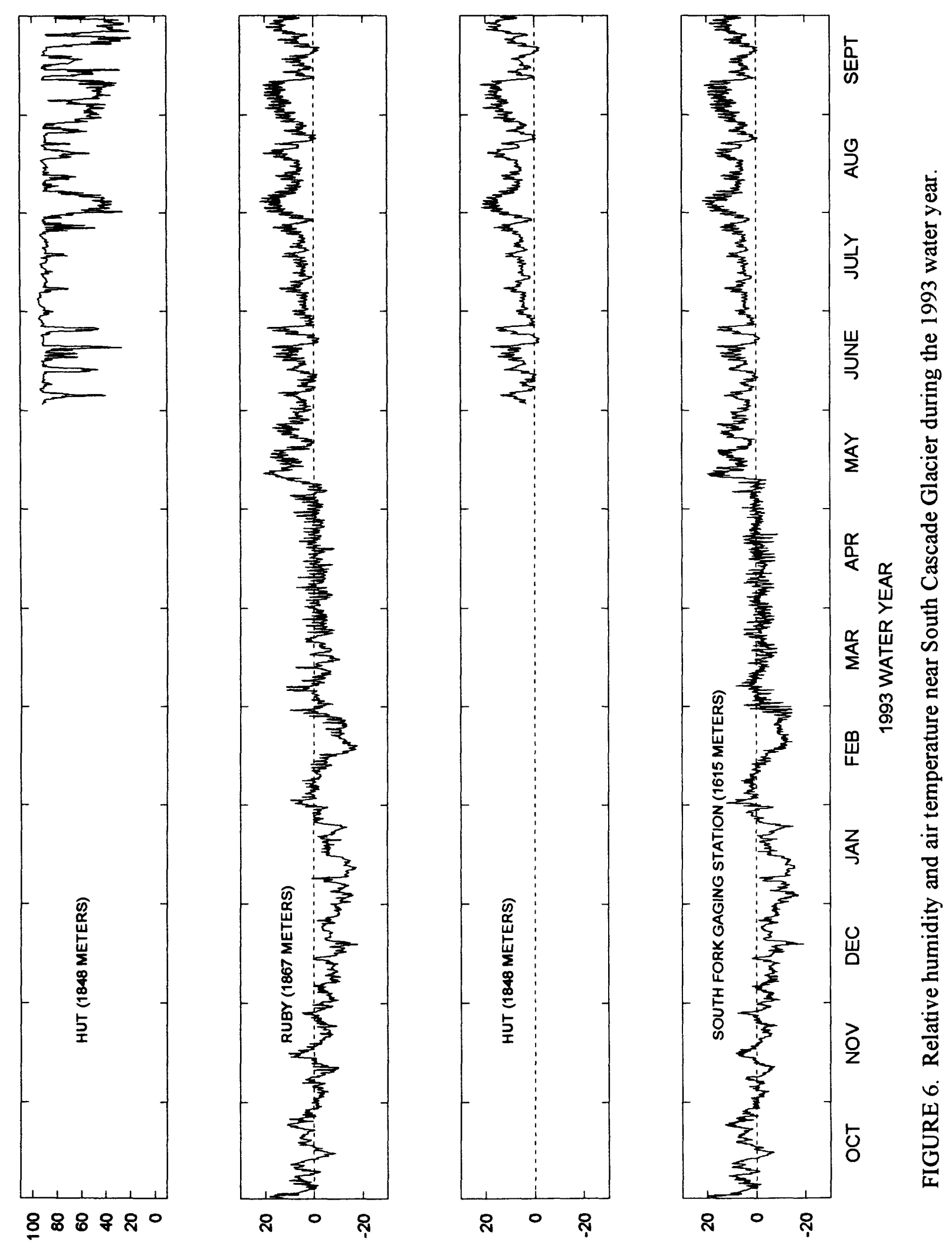

INヨวУヨd NI ' 


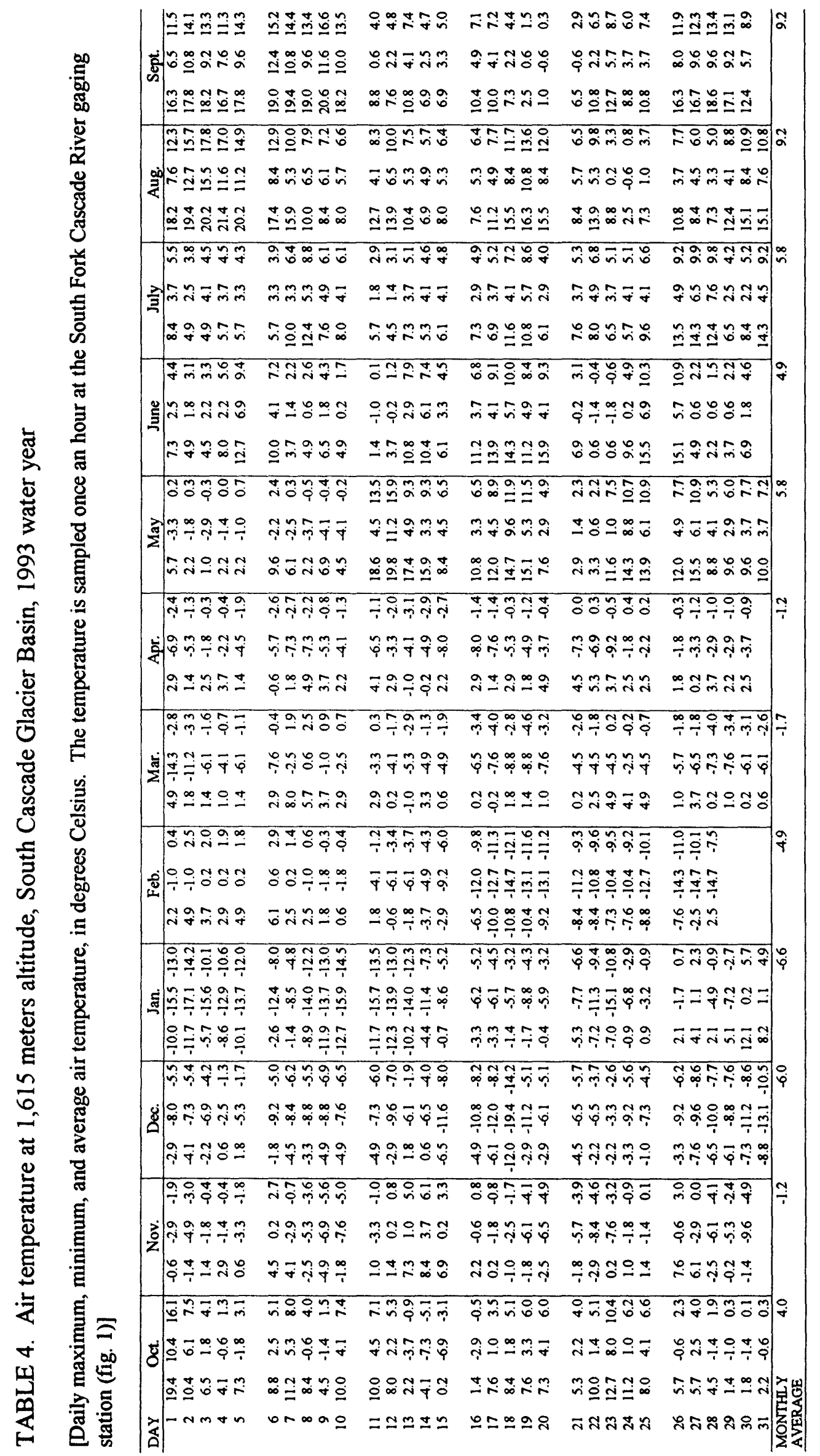




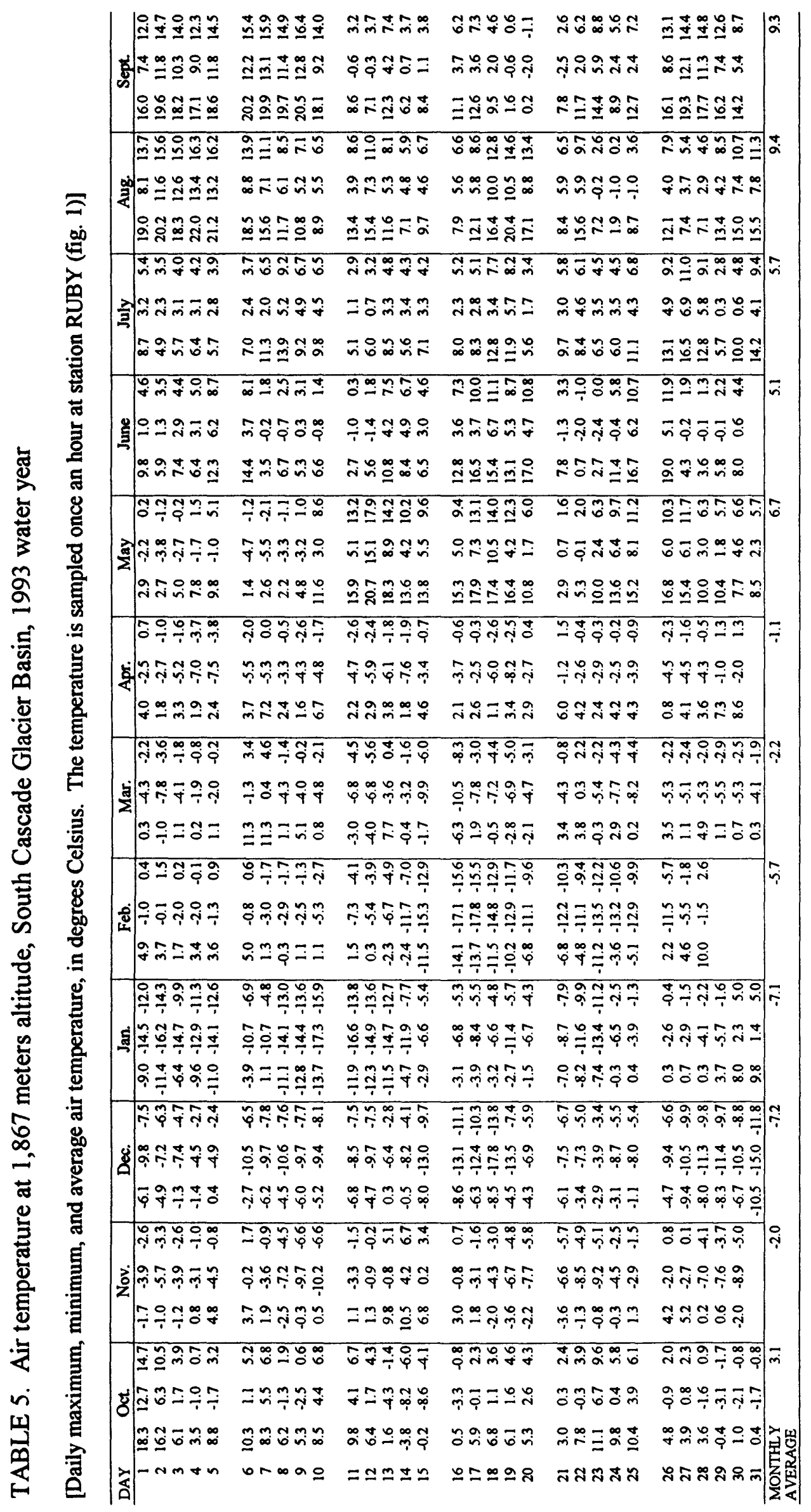


TABLE 6. Air temperature at 1,848 meters altitude, South Cascade Glacier Basin, June through September 1993

[Daily maximum, minimum, and average air temperature, in degrees Celsius. The temperature is sampled once an hour at the Hut (see fig. 1)]

\begin{tabular}{|c|c|c|c|c|c|c|c|c|c|c|c|c|}
\hline \multirow{2}{*}{$\frac{\text { Day }}{1}$} & \multicolumn{3}{|c|}{ June } & \multicolumn{3}{|c|}{ July } & \multicolumn{3}{|c|}{ Aug. } & \multicolumn{3}{|c|}{ Sept. } \\
\hline & & & & 7.2 & 3.5 & 5.4 & 17.5 & 10.0 & 13.9 & 15.7 & 8.7 & 12.0 \\
\hline 2 & & & & 5.2 & 2.5 & 3.7 & 21.6 & 12.6 & 16.3 & 20.6 & 12.2 & 15.3 \\
\hline 3 & 6.1 & 3.3 & 3.9 & 4.8 & 3.9 & 4.3 & 21.0 & 14.0 & 16.8 & 17.5 & 11.5 & 14.7 \\
\hline 4 & 8.6 & 3.6 & 6.0 & 5.8 & 4.0 & 4.7 & 20.7 & 14.4 & 16.8 & 15.1 & 10.4 & 12.1 \\
\hline 5 & 13.6 & 7.2 & 9.9 & 5.7 & 3.7 & 4.4 & 19.4 & 14.6 & 16.7 & 19.6 & 10.9 & 14.9 \\
\hline 6 & 10.0 & 3.4 & 7.7 & 5.5 & 3.2 & 4.1 & 16.9 & 10.2 & 14.2 & 19.9 & 13.2 & 15.8 \\
\hline 7 & 2.5 & 0.2 & 1.4 & 9.4 & 3.0 & 5.5 & 14.2 & 7.9 & 11.0 & 18.6 & 14.7 & 16.3 \\
\hline 8 & 5.0 & -0.5 & 1.9 & 12.3 & 6.8 & 9.0 & 10.8 & 6.5 & 8.0 & 17.8 & 13.1 & 15.1 \\
\hline 9 & 5.9 & 1.0 & 3.6 & 7.3 & 5.4 & 6.3 & 8.9 & 5.5 & 6.6 & 21.9 & 14.3 & 17.2 \\
\hline 10 & 3.8 & -0.5 & 1.2 & 7.6 & 5.0 & 6.2 & 7.8 & 5.6 & 6.4 & 17.0 & 11.1 & 14.6 \\
\hline 11 & 0.9 & -0.6 & 0.2 & 5.4 & 1.7 & 3.0 & 12.4 & 4.6 & 8.2 & 10.6 & 0.0 & 3.7 \\
\hline 12 & 5.2 & -0.9 & 1.8 & 5.1 & 1.5 & 2.8 & 13.1 & 7.0 & 10.5 & 7.1 & 0.0 & 3.2 \\
\hline 13 & 12.1 & 4.1 & 8.2 & 6.4 & 4.3 & 4.8 & 9.7 & 5.7 & 6.8 & 10.4 & 5.1 & 7.2 \\
\hline 14 & 9.0 & 5.5 & 6.0 & 5.5 & 4.3 & 3.2 & 6.3 & 5.1 & 5.6 & 6.8 & 0.8 & 4.1 \\
\hline 15 & 5.7 & 3.2 & 3.7 & 6.2 & 4.3 & 4.8 & 8.0 & 5.1 & 6.7 & 5.8 & 1.5 & 3.6 \\
\hline 16 & 10.4 & 4.1 & 6.8 & 6.7 & 3.1 & 4.3 & 7.9 & 6.4 & 7.1 & 4.8 & 4.3 & 1.3 \\
\hline 17 & 14.6 & 4.9 & 9.9 & 6.9 & 3.9 & 5.2 & 11.1 & 6.6 & 7.8 & 9.1 & 5.0 & 5.2 \\
\hline 18 & 13.4 & 7.9 & 10.3 & 11.5 & 4.7 & 7.1 & 16.1 & 10.7 & 12.6 & 5.8 & 2.0 & 4.1 \\
\hline 19 & 10.6 & 5.8 & 8.2 & 11.4 & 6.8 & 7.4 & 18.9 & 11.9 & 13.6 & 1.6 & -0.5 & 0.4 \\
\hline 20 & 17.7 & 5.4 & 10.7 & 6.6 & 2.5 & 3.8 & 15.1 & 9.1 & 13.5 & -0.5 & -2.1 & -1.3 \\
\hline 21 & 7.9 & -1.5 & 2.9 & 8.3 & 4.0 & 5.8 & 8.6 & 5.9 & 6.6 & 6.5 & -2.2 & 2.0 \\
\hline 22 & -0.8 & -2.0 & -1.5 & 8.0 & 5.3 & 6.5 & 13.0 & 6.3 & 7.3 & 10.8 & 3.2 & 6.8 \\
\hline 23 & 0.4 & -2.1 & -0.7 & 6.0 & 4.3 & 5.1 & 8.0 & 0.3 & 3.5 & 11.8 & 7.8 & 7.6 \\
\hline 24 & 9.4 & 0.4 & 4.9 & 6.0 & 4.5 & 5.3 & 0.5 & -0.8 & -0.1 & 8.6 & 2.4 & 6.2 \\
\hline 25 & 14.6 & 7.5 & 10.9 & 8.8 & 5.5 & 7.0 & 5.3 & -0.6 & 2.6 & 11.6 & 2.7 & 6.9 \\
\hline 26 & 15.5 & 4.8 & 11.6 & 13.2 & 6.3 & 8.9 & 11.3 & 4.4 & 7.8 & 19.4 & 9.8 & 14.3 \\
\hline 27 & 4.1 & -0.2 & 1.2 & 16.2 & 8.4 & 10.4 & 7.2 & 4.0 & 5.5 & 18.4 & 13.5 & 15.5 \\
\hline 28 & 1.4 & -0.3 & 0.7 & 13.2 & 6.7 & 9.2 & 5.9 & 2.9 & 4.3 & 19.6 & 13.4 & 15.9 \\
\hline 29 & 3.0 & 0.3 & 1.3 & 6.1 & 0.8 & 2.9 & 12.3 & 5.3 & 8.8 & 15.6 & 9.1 & 13.8 \\
\hline 30 & 6.4 & 1.2 & 3.9 & 7.8 & 0.9 & 4.1 & 16.5 & 7.5 & 11.2 & 13.4 & 6.6 & 9.1 \\
\hline 31 & & & & 13.9 & 4.8 & 9.6 & 14.6 & 9.7 & 11.8 & & & \\
\hline $\begin{array}{l}\text { MONT } \\
\text { AVERA }\end{array}$ & $\begin{array}{l}\mathrm{HLY} \\
\mathrm{AGE}\end{array}$ & & 4.9 & & & 5.6 & & & 9.3 & & & 9.3 \\
\hline
\end{tabular}

TABLE 7. Precipitation at 1,631 meters altitude, South Cascade Glacier Basin, July 1993

[Precipitation is sampled once every 15 minutes, and the daily sum is given in millimeters]

\begin{tabular}{rrrrrr}
\hline Day & Precipitation & Day & Precipitation & Day & Precipitation \\
\hline 1 & & 11 & 10.9 & 21 & 2.3 \\
2 & 3.8 & 12 & 13.7 & 22 & 1.5 \\
3 & 3.8 & 13 & 5.8 & 23 & 3.6 \\
4 & 2.0 & 14 & 6.4 & 24 & 8.6 \\
5 & 1.3 & 15 & 9.9 & 25 & 0.8 \\
& & & & & \\
6 & 0.5 & 16 & 2.0 & 26 & 0.0 \\
7 & 0.0 & 17 & 17.3 & 27 & 10.2 \\
8 & 0.5 & 18 & 7.6 & 28 & 14.2 \\
9 & 0.0 & 19 & 8.6 & 29 & \\
10 & 0.5 & 20 & 47.5 & 30 & \\
& & & & 31 & \\
\hline
\end{tabular}




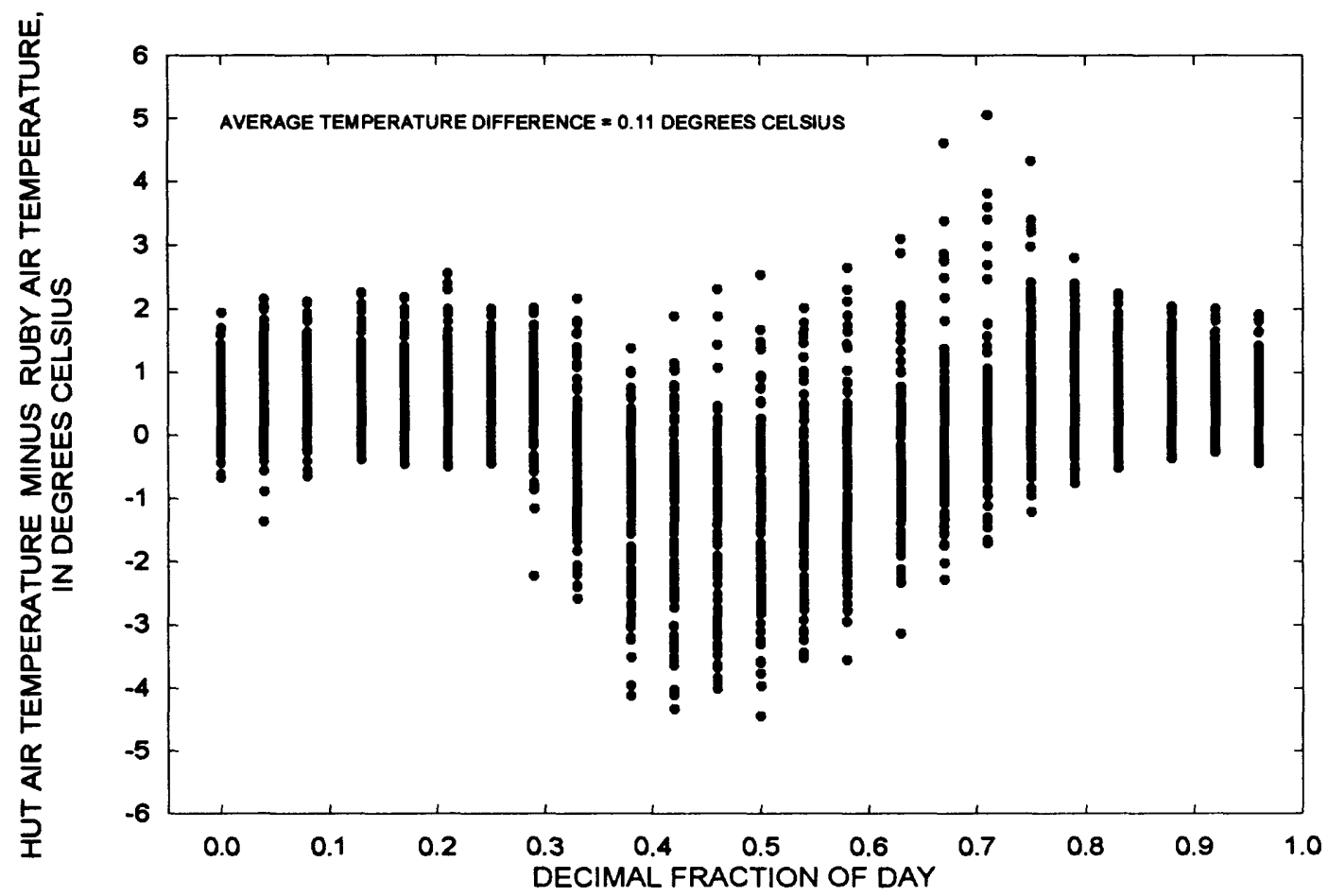

FIGURE 7. Air temperature differences between stations Hut and Ruby, South Cascade Glacier, June to September 1993.

Precipitation is measured near the Middle Tarn at $1,631 \mathrm{~m}$ altitude using a tipping bucket gage with a sensitivity of $0.0254 \mathrm{~mm}$ of precipitation. The cumulative precipitation for each 15 minute interval is relayed through the DCP. The $0.2-\mathrm{m}$ orifice of the gage is about $1 \mathrm{~m}$ above ground level. There is no wind shield on this gage. It is suspected that the gaged precipitation, as reported, is not representative of the true average precipitation in the basin because of the variability of precipitation within the basin. Precipitation was measured during most of July 1993.

The stage of Middle Tarn is measured in a stilling well at the edge of the tarn about $50 \mathrm{~m}$ from the outlet stream. The stage is sensed by a float attached to a potentiometer, and is recorded at 15-minute intervals on a data logger. This stage record is accurate to $3 \mathrm{~mm}$. The well was frozen from early December to mid-May 1993.

Water stage is recorded at the Salix Creek gaging station on an analog strip chart and independently on a data logger at 15 -minute intervals. The stage record is accurate to $3 \mathrm{~mm}$.

The stage of South Cascade Lake is measured near the outlet to the South Fork Cascade River about $10 \mathrm{~m}$ from the South Fork Cascade gaging station. Lake stage is sensed by a float in a well attached to a potentiometer. Stage is sampled at 15-minute intervals and recorded on a data logger. These stage records are accurate to $3 \mathrm{~mm}$. The water in the well was frozen from early December to early May 1993. 


\section{Aerial Photography}

Aerial photography provides an accurate record of a glacier at a specific time. A calibrated $230 \times 230$-mm-format camera with a $150 \mathrm{~mm}$ lens was used for the vertical photography. On September 1, 1993, nearly the entire basin was photographed at 1:16,000 scale (fig. 8), and most of the glacier was photographed at 1:8,000 scale.

The September 1 photographs were used to measure the transient snow line (fig. 1), a surface altitude grid over most of the glacier (fig. 9, table 8), and the terminus position (fig. 5). Stereo photogrammetry was used for these measurements, and was done by using standard photogrammetric procedures. At grid points where it was not possible to obtain a good stereo view (usually because of featureless snow), and thus rendering the measured grid point altitude potentially inaccurate, there is no value shown on figure 5 . All photogrammetrically measured altitudes are accurate to $1 \mathrm{~m}$ in horizontal and vertical location; however, the actual altitude measurement may be up to $10 \mathrm{~m}$ from the nominal grid point.

On September 27, 1993, a 35-mm-format camera was used to obtain oblique aerial photographs of most of the basin. These photographs were used to estimate the position of the firn line (fig. 1), which was slightly higher in altitude than the transient snow line on September 27.

\section{GLACIER LENGTH AND AREA MEASUREMENTS}

A concise method to measure the length and area of a glacier has not been devised. Both measurements require a distinct glacier perimeter, but the actual perimeter may difficult to define. The lower part of the glacier usually has some well-defined ice margins, but may also have a thick debris cover completely obscuring the ice edge. The limits of the accumulation zone may be especially uncertain. Excess melt of perennial marginal snow during an unusually warm fall may remove large areas of what had previously been considered part of the glacier. The converse may occur in a year of heavy snow or reduced melt when large areas of perennial snow are added to the margins of the glacier. In either case, the area of the glacier could change dramatically from year to year, depending on how the limits of the glacier are defined.

The length measurement of the glacier may also be dependent on poorly defined ice margins. In addition, some method to average the finite width of the glacier must be devised, and if the glacier is sinuous, then a curvilinear center line must be defined.

Problems in measuring the length and area of a glacier are avoided at South Cascade Glacier by emphasizing changes, rather than the absolute values. The margin of the glacier south of local $\mathrm{Y}=3,300 \mathrm{~m}$ is taken to be identical in 1992 and 1993. The area of South Cascade Glacier north of local $\mathrm{Y}=3,300 \mathrm{~m}$ decreased by $0.011 \mathrm{~km}^{2}$ from October 6, 1992 to September 1, 1993. The 1993 area of South Cascade Glacier, measured by this method, is $2.078 \mathrm{~km}^{2}$. This area measurement is more precise than that made by accumulating the number of grid cells that cover the glacier as is done later in this report. The grid-cell-area may differ from the measured area depending on how many grid centers fall within the glacier confines. 


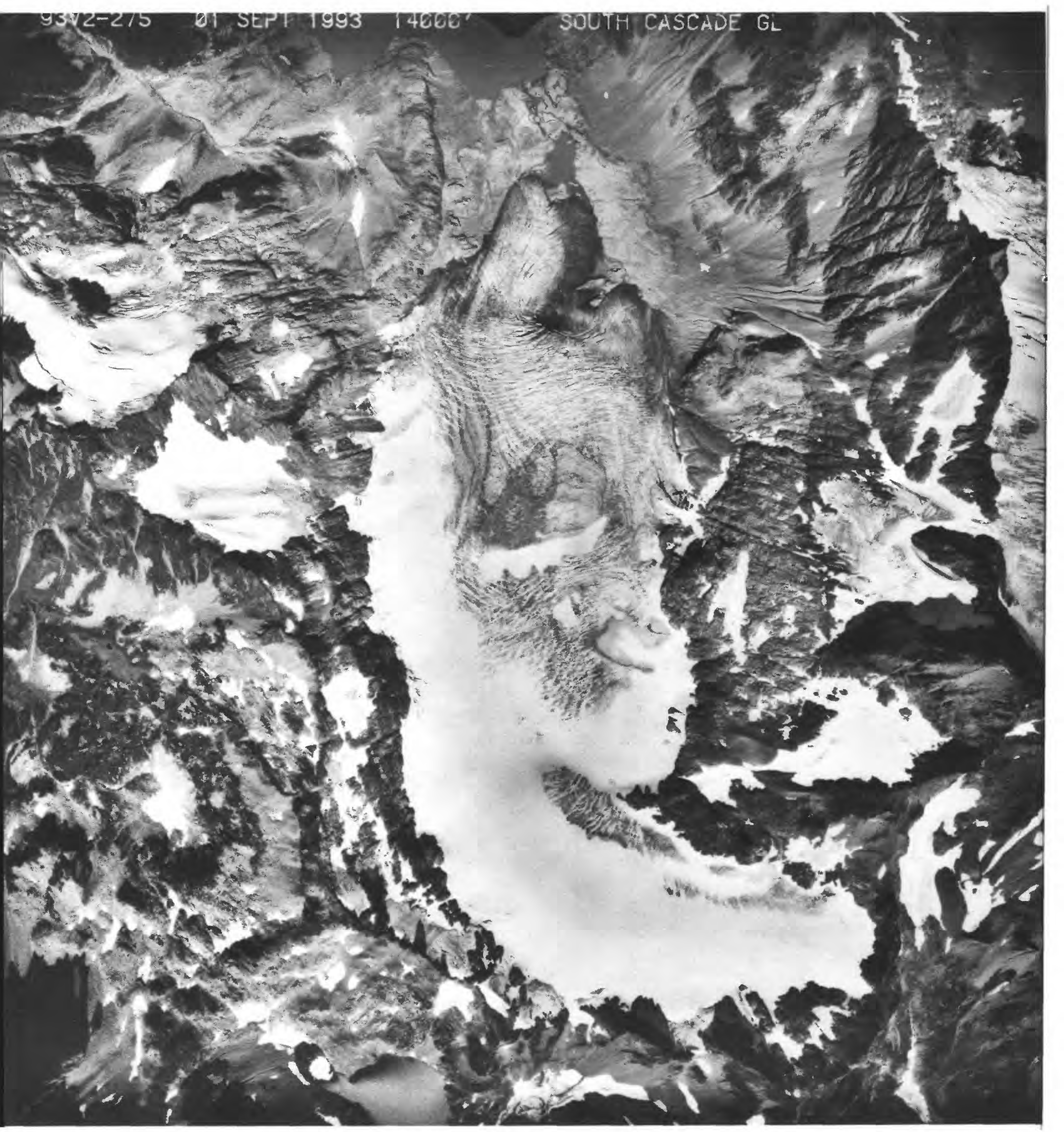

FIGURE 8. Vertical photograph of South Cascade Glacier, September 1, 1993.

The maximum width of the glacier is about 1 kilometer, north is approximately up. 


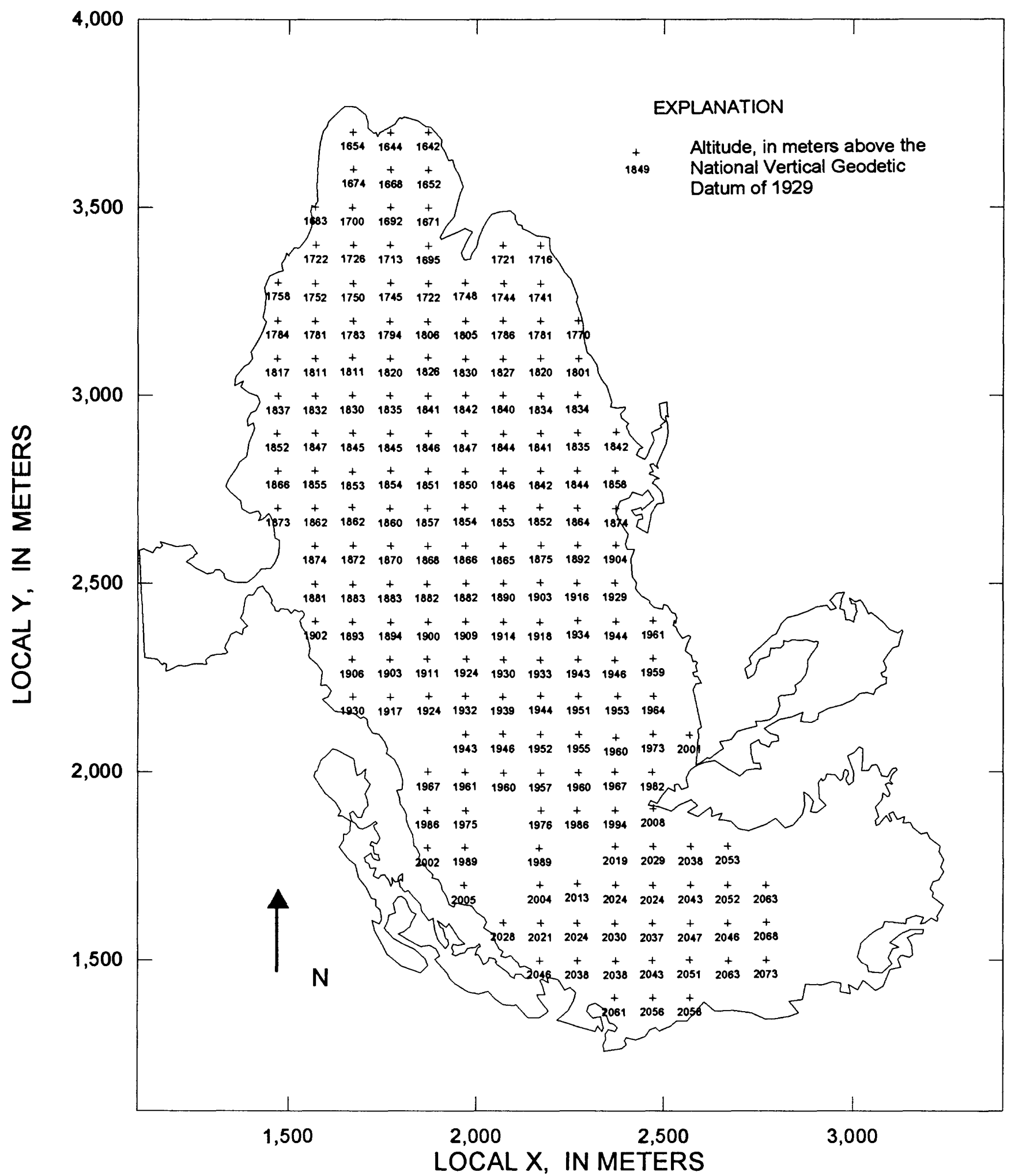

FIGURE 9. Altitude grid for South Cascade Glacier, measured from stereo vertical photographs taken on September 1, 1993. 
TABLE 8. South Cascade Glacier altitude grid, September 1, 1993

[Surface altitude (Z), in meters above National Geodetic Vertical Datum of 1929, was measured near the nominal point for each grid cell. Coordinates $\mathrm{X}$ and $\mathrm{Y}$ are local (see fig. 5). The tenths of meters are marginally significant]

\begin{tabular}{|c|c|c|c|c|c|c|c|c|c|c|c|}
\hline $\mathrm{X}$ & $\mathrm{Y}$ & $\mathrm{Z}$ & $\mathrm{X}$ & $\bar{Y}$ & $\mathrm{Z}$ & $X$ & $\mathrm{Y}$ & $\mathrm{Z}$ & $X$ & $Y$ & $\mathrm{Z}$ \\
\hline 1670.4 & 3700.8 & 1654.2 & 1769.5 & 2999.8 & 1835.4 & 1569.8 & 2498.5 & 1881.2 & 1969.9 & 1998.8 & 1960.9 \\
\hline 1769.9 & 3698.8 & 1644.4 & 1870.9 & 2999.0 & 1840.6 & 1670.8 & 2498.7 & 1883.2 & 2071.9 & 1996.6 & 1959.9 \\
\hline 1869.9 & 3700.0 & 1641.5 & 1970.1 & 3001.2 & 1841.7 & 1769.5 & 2498.4 & 1883.1 & 2170.3 & 1997.5 & 1957.2 \\
\hline 1671.9 & 3601.5 & 1674.3 & 2070.5 & 3000.8 & 1840.0 & 1868.1 & 2499.2 & 1881.9 & 2273.0 & 1997.5 & 1959.6 \\
\hline 1770.1 & 3599.6 & 1668.1 & 2171.0 & 2998.9 & 1834.3 & 1971.5 & 2501.0 & 1881.5 & 2369.3 & 2000.5 & 1966.6 \\
\hline 1871.4 & 3599.2 & 1652.0 & 2269.1 & 3001.3 & 1834.1 & 2071.1 & 2500.9 & 1890.1 & 2468.8 & 1998.8 & 1981.8 \\
\hline 1570.9 & 3501.7 & 1682.9 & 1468.4 & 2899.6 & 1851.7 & 2169.6 & 2502.8 & 1903.3 & 1869.2 & 1898.1 & 1986.0 \\
\hline 1669.0 & 3500.5 & 1699.8 & 1570.3 & 2900.3 & 1846.8 & 2268.3 & 2502.0 & 1916.2 & 1971.3 & 1898.8 & 1974.8 \\
\hline 1770.0 & 3500.8 & 1691.5 & 1669.8 & 2900.4 & 1845.3 & 2369.1 & 2502.8 & 1929.4 & 2171.6 & 1897.6 & 1975.6 \\
\hline 1871.2 & 3499.2 & 1670.8 & 1769.0 & 2898.3 & 1845.1 & 1570.8 & 2399.8 & 1901.9 & 2268.4 & 1897.7 & 1986.0 \\
\hline 1571.8 & 3401.0 & 1722.4 & 1870.7 & 2898.9 & 1846.0 & 1668.7 & 2399.2 & 1893.3 & 2370.0 & 1898.2 & 1993.6 \\
\hline 1671.2 & 3401.7 & 1726.3 & 1968.7 & 2898.9 & 1847.1 & 1770.4 & 2398.0 & 1893.9 & 2470.8 & 1903.1 & 2008.3 \\
\hline 1769.9 & 3399.3 & 1713.0 & 2070.3 & 2899.3 & 1844.2 & 1870.9 & 2398.4 & 1899.6 & 1870.1 & 1797.8 & 2001.9 \\
\hline 1870.7 & 3398.8 & 1695.3 & 2169.8 & 2900.6 & 1841.4 & 1970.7 & 2399.4 & 1908.8 & 1970.3 & 1799.6 & 1989.4 \\
\hline 2070.6 & 3399.9 & 1721.1 & 2269.4 & 2900.9 & 1835.1 & 2070.9 & 2398.6 & 1914.4 & 2168.4 & 1798.2 & 1989.0 \\
\hline 2170.0 & 3400.3 & 1716.2 & 2371.2 & 2902.0 & 1842.2 & 2168.6 & 2399.0 & 1917.9 & 2370.7 & 1802.7 & 2018.9 \\
\hline 1470.8 & 3302.2 & 1757.7 & 1470.9 & 2799.5 & 1866.3 & 2270.0 & 2402.5 & 1934.0 & 2470.8 & 1802.7 & 2029.2 \\
\hline 1569.8 & 3298.6 & 1751.6 & 1569.4 & 2800.2 & 1855.4 & 2371.0 & 2399.9 & 1943.5 & 2570.8 & 1801.9 & 2037.5 \\
\hline 1670.5 & 3299.1 & 1750.3 & 1670.0 & 2798.0 & 1853.4 & 2470.7 & 2402.1 & 1960.8 & 2669.1 & 1803.2 & 2053.4 \\
\hline 1770.4 & 3299.8 & 1745.3 & 1770.7 & 2799.8 & 1853.5 & 1668.6 & 2299.3 & 1906.2 & 1967.2 & 1699.0 & 2004.5 \\
\hline 1870.9 & 3298.3 & 1721.7 & 1871.1 & 2799.1 & 1850.6 & 1769.5 & 2299.8 & 1903.3 & 2169.5 & 1699.8 & 2004.3 \\
\hline 1968.8 & 3302.1 & 1747.5 & 1970.1 & 2799.5 & 1849.8 & 1868.8 & 2300.4 & 1911.4 & 2268.9 & 1703.5 & 2012.8 \\
\hline 2070.9 & 3299.4 & 1744.1 & 2070.0 & 2799.2 & 1846.0 & 1972.3 & 2301.5 & 1923.5 & 2371.0 & 1700.7 & 2023.6 \\
\hline 2170.1 & 3298.5 & 1741.3 & 2170.6 & 2798.9 & 1842.0 & 2071.1 & 2298.6 & 1930.3 & 2469.8 & 1698.9 & 2023.6 \\
\hline 1470.0 & 3200.1 & 1784.2 & 2268.4 & 2800.3 & 1844.0 & 2169.7 & 2299.0 & 1933.0 & 2570.6 & 1699.7 & 2043.4 \\
\hline 1570.8 & 3199.3 & 1780.5 & 2368.7 & 2800.9 & 1857.9 & 2271.4 & 2299.3 & 1943.0 & 2669.1 & 1699.8 & 2052.1 \\
\hline 1670.8 & 3199.1 & 1783.3 & 1471.1 & 2698.5 & 1872.6 & 2368.4 & 2298.0 & 1946.4 & 2769.8 & 1699.9 & 2062.8 \\
\hline 1768.9 & 3198.6 & 1794.4 & 1570.8 & 2698.9 & 1862.2 & 2470.3 & 2302.1 & 1958.7 & 2071.8 & 1600.8 & 2028.1 \\
\hline 1869.0 & 3198.5 & 1805.5 & 1669.6 & 2701.2 & 1861.5 & 1670.3 & 2199.9 & 1930.1 & 2172.1 & 1599.1 & 2021.1 \\
\hline 1970.8 & 3198.9 & 1805.1 & 1769.0 & 2697.4 & 1860.2 & 1770.0 & 2198.7 & 1917.2 & 2269.0 & 1599.2 & 2023.9 \\
\hline 2070.4 & 3199.0 & 1785.9 & 1869.4 & 2698.5 & 1857.3 & 1873.0 & 2200.7 & 1923.7 & 2369.5 & 1599.1 & 2030.3 \\
\hline 2170.1 & 3199.1 & 1780.7 & 1969.2 & 2702.0 & 1854.0 & 1969.3 & 2201.9 & 1932.4 & 2469.3 & 1598.3 & 2036.6 \\
\hline 2271.1 & 3199.2 & 1769.6 & 2069.2 & 2698.7 & 1852.7 & 2069.3 & 2199.9 & 1938.8 & 2570.5 & 1598.3 & 2046.6 \\
\hline 1469.4 & 3099.5 & 1816.7 & 2168.8 & 2701.2 & 1851.7 & 2171.0 & 2202.3 & 1944.0 & 2669.7 & 1598.9 & 2046.4 \\
\hline 1570.0 & 3098.8 & 1810.9 & 2269.4 & 2699.9 & 1863.7 & 2272.1 & 2201.5 & 1950.6 & 2771.9 & 1602.1 & 2068.4 \\
\hline 1669.0 & 3101.7 & 1811.0 & 2371.5 & 2698.2 & 1874.3 & 2375.8 & 2202.0 & 1953.0 & 2169.1 & 1499.1 & 2046.1 \\
\hline 1769.2 & 3099.5 & 1820.4 & 1569.5 & 2599.4 & 1873.6 & 2470.8 & 2202.0 & 1963.8 & 2269.8 & 1498.4 & 2038.2 \\
\hline 1869.8 & 3101.5 & 1826.1 & 1671.6 & 2600.3 & 1871.7 & 1970.3 & 2100.0 & 1942.8 & 2371.9 & 1498.1 & 2037.6 \\
\hline 1969.4 & 3099.5 & 1830.1 & 1770.5 & 2599.0 & 1870.3 & 2069.7 & 2099.7 & 1946.4 & 2468.4 & 1500.0 & 2042.8 \\
\hline 2069.3 & 3098.6 & 1827.3 & 1870.0 & 2598.8 & 1868.1 & 2170.8 & 2099.2 & 1951.7 & 2568.4 & 1501.1 & 2050.5 \\
\hline 2170.4 & 3100.4 & 1819.5 & 1970.1 & 2600.5 & 1866.2 & 2272.8 & 2099.6 & 1955.1 & 2670.8 & 1499.7 & 2063.3 \\
\hline 2270.7 & 3098.8 & 1801.4 & 2070.2 & 2599.6 & 1864.6 & 2371.9 & 2091.0 & 1959.6 & 2770.9 & 1500.3 & 2073.0 \\
\hline 1471.7 & 2998.8 & 1837.4 & 2171.6 & 2601.5 & 1874.9 & 2470.7 & 2100.2 & 1973.0 & 2369.4 & 1399.1 & 2061.0 \\
\hline 1570.1 & 2998.3 & 1831.8 & 2270.3 & 2601.9 & 1892.4 & 2567.9 & 2098.2 & 2001.0 & 2470.1 & 1399.8 & 2056.4 \\
\hline 1668.7 & 2999.3 & 1830.4 & 2370.7 & 2601.5 & 1903.8 & 1871.5 & 2000.1 & 1967.0 & 2569.6 & 1399.4 & 2058.4 \\
\hline
\end{tabular}


By arbitrarily considering the glacier to be $0.5 \mathrm{~km}$ wide at the terminus, the length change for that period is $-0.022 \mathrm{~km}$. The distribution of these changes, which are greater toward the northeast part of the terminus area, is shown in figure 10 .

The ratio of accumulation area to total glacier area (AAR) was 0.17 in 1993 . The equilibrium altitude (ELA), the approximate maximum altitude reached by the 1993 transient snowline, was $1986 \mathrm{~m}$ for the 1993 balance year.

\section{RUNOFF AND PRECIPITATION}

A river or lake stage record may be converted to a volume of discharge/unit time record if the relation between stage and discharge (the rating curve) is known.

Rating curves for the South Fork Cascade River and Salix Creek have been previously established and were used to make the stage-to-discharge conversions, shown as runoff, in millimeters per day in figure 11 and tables 9 and 10. The rating curve for Middle Tarn was established using 11 discharge measurements made during 1992 and 1993 (table 11); the daily runoff is shown in table 12 .

The time series of daily runoff are what would be expected from high altitude nonglacierized and glacierized basins in the North Cascade Range. Maximum runoff occurs from Salix Basin during hot weather when the basin is mostly snow covered. By late June, most of the snow was melted, and runoff peaks later in the summer and fall were due to rain. South Cascade Lake Basin, which is 41 percent glacierized, has high runoff during warm weather in May when it is mostly snow covered. Runoff remains high through the warm weather of summer when snow and ice melt are the main contributors of water. Middle Tarn Basin, which is 56 percent glacierized, also has its peak runoff in mid- to late summer when snow and ice melt are the dominant water source. It is also known that the glacier stores water during the spring melt period, and releases that stored water during the summer (Tangborn and others, 1975). Each of the basins may have very high runoff associated with fall season rain when there is little or no snow to attenuate the runoff peak. One of these storms occurred in early November 1992 (fig. 11), but the storm was not of high enough intensity to produce extreme runoff.

Precipitation was measured directly only during part of July 1993. An indirect measure of rainfall can be derived from the Salix Basin runoff after most of the snow has melted from the basin. The relation between Salix Basin runoff and precipitation is shown in figure 12. A similar relation of precipitation to the glacierized basins is not valid because of the dominance of snow and ice melt derived runoff in those basins. 


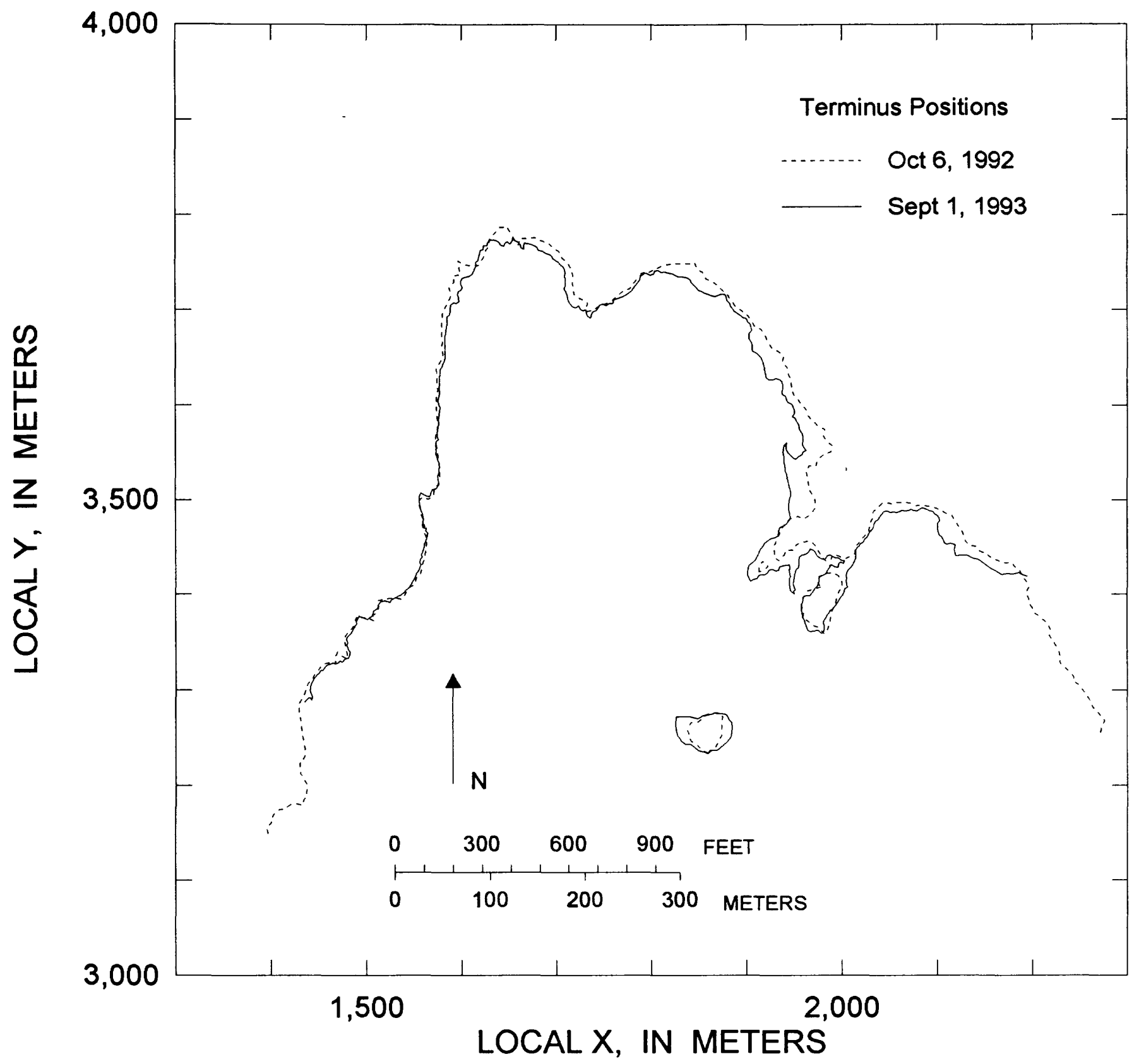

FIGURE 10. South Cascade Glacier terminus positions for October 6, 1992 and September 1, 1993. 


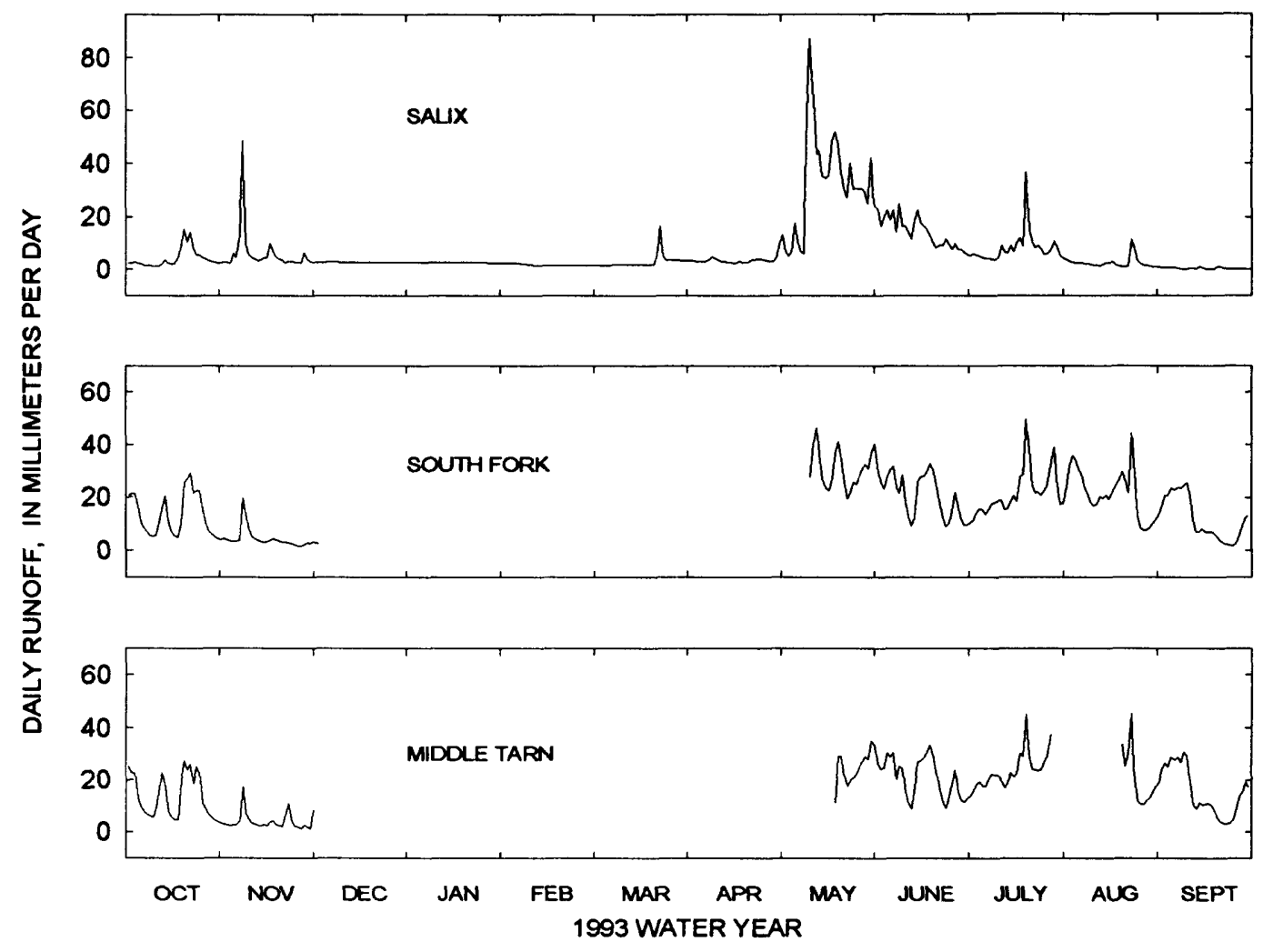

FIGURE 11. Daily runoff from South Cascade Glacier Basin, Middle Tarn Basin, and Salix Basin, 1993 water year.

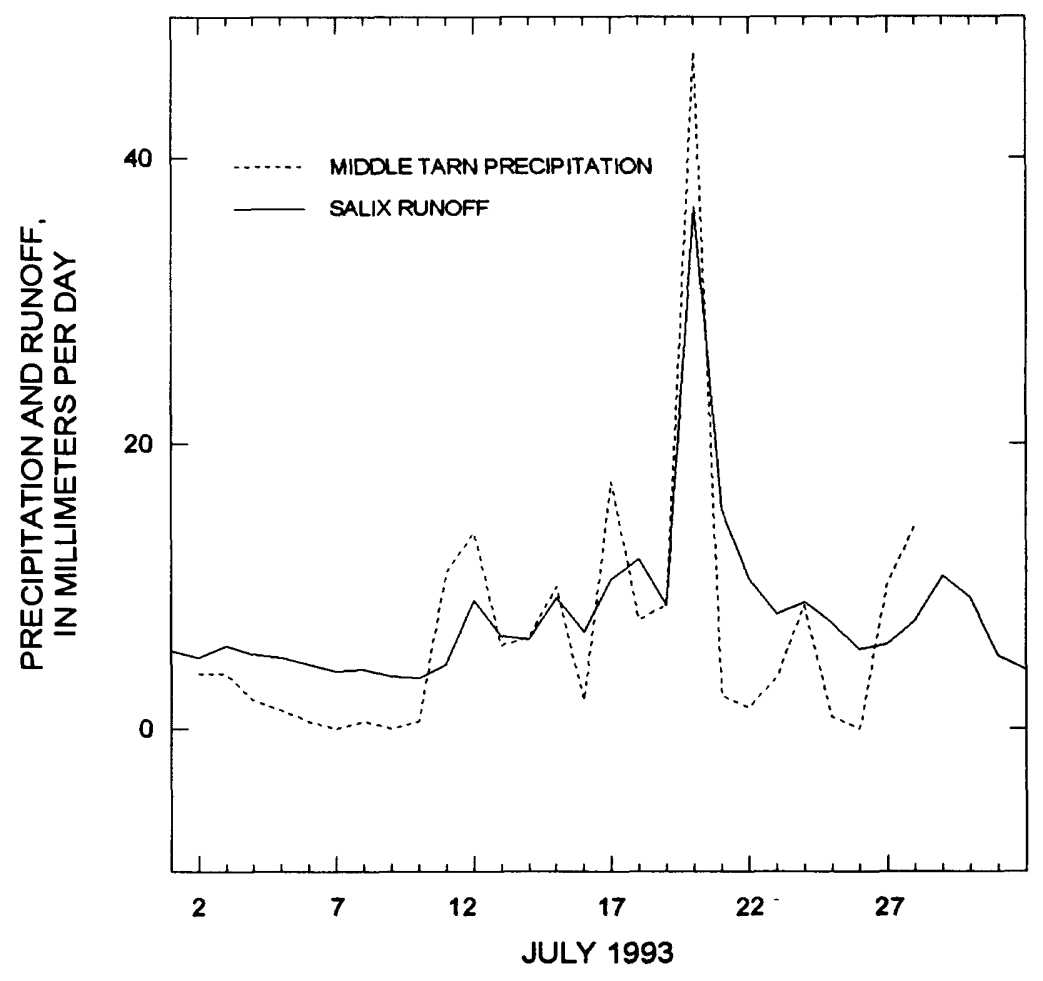

FIGURE 12. Precipitation at Middle Tarn station and runoff from Salix Basin during July 1993. 
TABLE 9. Runoff at South Cascade Glacier Basin, 1993 water year

[Values in millimeters, averaged over the basin; no data indicated by -99.0]

\begin{tabular}{|c|c|c|c|c|c|c|c|c|c|c|c|c|}
\hline DAY & Oct. & Nov. & Dec. & Jan. & Feb. & Mar. & Apr. & May & June & July & Aug. & Sept. \\
\hline 1 & 20.8 & 4.4 & 2.8 & -99.0 & -99.0 & -99.0 & -99.0 & -99.0 & 40.4 & 9.6 & 17.6 & 13.2 \\
\hline 2 & 21.2 & 4.0 & 2.2 & -99.0 & -99.0 & -99.0 & -99.0 & -99.0 & 29.6 & 10.4 & 23.6 & 16.8 \\
\hline 3 & 21.2 & 3.4 & -99.0 & -99.0 & -99.0 & -99.0 & -99.0 & -99.0 & 25.6 & 11.2 & 32.0 & 20.8 \\
\hline 4 & 16.4 & 3.6 & -99.0 & -99.0 & -99.0 & -99.0 & -99.0 & -99.0 & 23.2 & 14.0 & 35.6 & 20.8 \\
\hline 5 & 10.8 & 3.6 & -99.0 & -99.0 & -99.0 & -99.0 & -99.0 & -99.0 & 27.6 & 15.6 & 34.0 & 23.2 \\
\hline 6 & 8.4 & 3.6 & -99.0 & -99.0 & -99.0 & -99.0 & -99.0 & -99.0 & 30.4 & 15.2 & 30.4 & 22.8 \\
\hline 7 & 6.8 & 19.6 & -99.0 & -99.0 & -99.0 & -99.0 & -99.0 & -99.0 & 31.6 & 13.6 & 28.4 & 23.6 \\
\hline 8 & 5.6 & 13.6 & -99.0 & -99.0 & -99.0 & -99.0 & -99.0 & -99.0 & 24.0 & 15.2 & 23.2 & 23.2 \\
\hline 9 & 5.2 & 8.0 & -99.0 & -99.0 & -99.0 & -99.0 & -99.0 & -99.0 & 21.6 & 17.6 & 21.2 & 24.4 \\
\hline 10 & 5.6 & 5.2 & -99.0 & -99.0 & -99.0 & -99.0 & -99.0 & -99.0 & 28.4 & 18.0 & 18.0 & 25.2 \\
\hline 11 & 10.4 & 4.4 & -99.0 & -99.0 & -99.0 & -99.0 & -99.0 & 27.6 & 18.4 & 18.8 & 16.8 & 20.8 \\
\hline 12 & 16.0 & 3.7 & -99.0 & -99.0 & -99.0 & -99.0 & -99.0 & 40.4 & 12.8 & 18.8 & 17.2 & 11.6 \\
\hline 13 & 20.4 & 3.2 & -99.0 & -99.0 & -99.0 & -99.0 & -99.0 & 46.4 & 9.2 & 15.2 & 20.0 & 6.8 \\
\hline 14 & 11.2 & 3.2 & -99.0 & -99.0 & -99.0 & -99.0 & -99.0 & 36.4 & 12.0 & 15.6 & 19.6 & 6.8 \\
\hline 15 & 7.2 & 3.3 & -99.0 & -99.0 & -99.0 & -99.0 & -99.0 & 26.8 & 26.0 & 18.4 & 20.8 & 8.0 \\
\hline 16 & 5.6 & 3.6 & -99.0 & -99.0 & -99.0 & -99.0 & -99.0 & 23.2 & 27.6 & 20.8 & 19.2 & 6.8 \\
\hline 17 & 4.8 & 4.4 & -99.0 & -99.0 & -99.0 & -99.0 & -99.0 & 22.4 & 28.0 & 18.4 & 22.4 & 6.8 \\
\hline 18 & 10.0 & 4.0 & -99.0 & -99.0 & -99.0 & -99.0 & -99.0 & 27.2 & 29.6 & 27.6 & 24.8 & 6.8 \\
\hline 19 & 25.6 & 3.6 & -99.0 & -99.0 & -99.0 & -99.0 & -99.0 & 36.8 & 32.8 & 28.4 & 26.4 & 6.4 \\
\hline 20 & 27.2 & 3.2 & -99.0 & -99.0 & -99.0 & -99.0 & -99.0 & 41.2 & 30.4 & 49.6 & 29.6 & 5.2 \\
\hline 21 & 29.2 & 3.0 & -99.0 & -99.0 & -99.0 & -99.0 & -99.0 & 34.4 & 24.8 & 38.0 & 26.0 & 3.8 \\
\hline 22 & 21.6 & 2.9 & -99.0 & -99.0 & -99.0 & -99.0 & -99.0 & 25.6 & 17.6 & 24.4 & 21.6 & 2.9 \\
\hline 23 & 22.4 & 2.6 & -99.0 & -99.0 & -99.0 & -99.0 & -99.0 & 19.6 & 12.4 & 21.6 & 44.4 & 2.2 \\
\hline 24 & 22.4 & 2.0 & -99.0 & -99.0 & -99.0 & -99.0 & -99.0 & 22.0 & 8.8 & 22.0 & 29.2 & 1.9 \\
\hline 25 & 15.6 & 1.7 & -99.0 & -99.0 & -99.0 & -99.0 & -99.0 & 25.6 & 10.0 & 20.8 & 13.2 & 1.8 \\
\hline 26 & 10.4 & 1.6 & -99.0 & -99.0 & -99.0 & -99.0 & -99.0 & 24.8 & 14.8 & 22.4 & 8.4 & 2.6 \\
\hline 27 & 7.2 & 2.1 & -99.0 & -99.0 & -99.0 & -99.0 & -99.0 & 28.0 & 22.0 & 24.8 & 7.6 & 5.6 \\
\hline 28 & 6.0 & 2.8 & -99.0 & -99.0 & -99.0 & -99.0 & -99.0 & 30.8 & 16.8 & 33.6 & 7.6 & 8.8 \\
\hline 29 & 5.2 & 2.7 & -99.0 & -99.0 & & -99.0 & -99.0 & 32.4 & 12.0 & 38.8 & 8.4 & 12.0 \\
\hline 30 & 4.4 & 3.1 & -99.0 & -99.0 & & -99.0 & -99.0 & 30.8 & 9.6 & 26.4 & 10.0 & 13.2 \\
\hline 31 & 4.0 & & -99.0 & -99.0 & & -99.0 & & 36.8 & & 17.2 & 11.6 & \\
\hline SUM & 408.8 & 130.2 & -- & -- & -- & -- & -- & -- & 658.0 & 662.0 & 668.8 & 354.9 \\
\hline
\end{tabular}


TABLE 10. Runoff at Salix Basin, 1993 water year

[Values in millimeters, averaged over the basin]

\begin{tabular}{|c|c|c|c|c|c|c|c|c|c|c|c|c|}
\hline DAY & Oct. & Nov. & Dec. & Jan. & Feb. & Mar. & Apr. & May & June & July & Aug. & Sept. \\
\hline 1 & 2.5 & 2.7 & 2.7 & 2.7 & 2.5 & 1.7 & 3.1 & 9.8 & 24.8 & 5.4 & 4.1 & 0.8 \\
\hline 2 & 2.4 & 2.6 & 2.7 & 2.7 & 2.5 & 1.7 & 3.1 & 13.0 & 22.4 & 5.0 & 3.5 & 0.7 \\
\hline 3 & 2.6 & 2.5 & 2.7 & 2.7 & 2.4 & 1.7 & 3.3 & 6.6 & 16.5 & 5.8 & 3.0 & 0.6 \\
\hline 4 & 2.4 & 6.1 & 2.7 & 2.7 & 2.4 & 1.7 & 3.3 & 4.8 & 20.1 & 5.2 & 2.7 & 0.6 \\
\hline 5 & 2.0 & 4.3 & 2.8 & 2.7 & 2.2 & 1.7 & 3.2 & 6.8 & 22.4 & 5.0 & 2.5 & 0.6 \\
\hline 6 & 1.7 & 13.0 & 2.8 & 2.7 & 2.1 & 1.7 & 3.1 & 17.7 & 18.9 & 4.5 & 2.2 & 0.6 \\
\hline 7 & 1.5 & 48.4 & 2.8 & 2.7 & 2.0 & 1.5 & 3.0 & 10.4 & 22.4 & 4.0 & 2.2 & 0.5 \\
\hline 8 & 1.4 & 9.2 & 2.8 & 2.7 & 1.9 & 1.8 & 3.5 & 6.7 & 14.2 & 4.1 & 2.0 & 0.2 \\
\hline 9 & 1.3 & 5.6 & 2.7 & 2.7 & 1.9 & 1.9 & 4.6 & 5.9 & 24.8 & 3.7 & 2.0 & 0.1 \\
\hline 10 & 1.2 & 4.3 & 2.7 & 2.7 & 1.7 & 1.9 & 4.1 & 59.0 & 16.5 & 3.5 & 1.9 & 0.1 \\
\hline 11 & 1.2 & 3.7 & 2.7 & 2.7 & 1.7 & 1.9 & 3.4 & 87.3 & 16.5 & 4.5 & 1.7 & 0.4 \\
\hline 12 & 2.0 & 3.3 & 2.7 & 2.7 & 1.7 & 1.9 & 3.1 & 68.4 & 14.2 & 9.0 & 1.4 & 0.4 \\
\hline 13 & 3.5 & 3.4 & 2.7 & 2.7 & 1.7 & 1.9 & 2.8 & 43.7 & 11.6 & 6.5 & 1.3 & 0.1 \\
\hline 14 & 2.4 & 4.3 & 2.7 & 2.7 & 1.7 & 1.9 & 2.7 & 44.8 & 18.9 & 6.3 & 1.9 & 0.8 \\
\hline 15 & 2.0 & 4.5 & 2.7 & 2.7 & 1.7 & 1.9 & 2.6 & 35.4 & 22.4 & 9.1 & 2.5 & 0.7 \\
\hline 16 & 2.0 & 9.9 & 2.7 & 2.7 & 1.7 & 1.9 & 2.5 & 34.2 & 17.7 & 6.7 & 2.4 & 0.2 \\
\hline 17 & 4.3 & 7.1 & 2.7 & 2.7 & 1.7 & 1.9 & 2.4 & 35.4 & 16.5 & 10.4 & 2.7 & 0.1 \\
\hline 18 & 8.9 & 4.7 & 2.7 & 2.7 & 1.7 & 1.9 & 2.8 & 48.4 & 15.3 & 11.8 & 1.7 & 0.1 \\
\hline 19 & 15.3 & 3.8 & 2.7 & 2.7 & 1.7 & 1.9 & 2.7 & 51.9 & 13.0 & 8.6 & 1.2 & 0.2 \\
\hline 20 & 10.4 & 3.4 & 2.7 & 2.7 & 1.7 & 1.9 & 2.7 & 47.2 & 10.2 & 36.6 & 1.1 & 0.8 \\
\hline 21 & 14.2 & 2.5 & 2.7 & 2.7 & 1.7 & 1.9 & 2.7 & 36.6 & 8.1 & 15.3 & 0.9 & 0.8 \\
\hline 22 & 8.1 & 3.0 & 2.7 & 2.7 & 1.7 & 5.2 & 3.4 & 30.7 & 9.3 & 10.4 & 1.2 & 0.5 \\
\hline 23 & 5.4 & 2.8 & 2.7 & 2.7 & 1.7 & 16.5 & 3.4 & 27.1 & 8.9 & 8.0 & 11.3 & 0.2 \\
\hline 24 & 5.4 & 2.7 & 2.7 & 2.7 & 1.7 & 5.0 & 3.8 & 40.1 & 11.7 & 8.9 & 7.9 & 0.1 \\
\hline 25 & 4.4 & 2.6 & 2.7 & 2.6 & 1.7 & 3.5 & 3.7 & 30.7 & 9.6 & 7.4 & 3.3 & 0.1 \\
\hline 26 & 3.8 & 2.2 & 2.7 & 2.5 & 1.7 & 3.4 & 3.5 & 30.7 & 7.7 & 5.6 & 2.0 & 0.1 \\
\hline 27 & 3.2 & 6.4 & 2.7 & 2.5 & 1.7 & 3.4 & 3.2 & 30.7 & 9.8 & 5.9 & 1.5 & 0.1 \\
\hline 28 & 3.0 & 3.7 & 2.7 & 2.5 & 1.7 & 3.4 & 3.0 & 30.7 & 7.6 & 7.6 & 1.5 & 0.1 \\
\hline 29 & 2.7 & 3.1 & 2.7 & 2.5 & & 3.4 & 3.1 & 29.5 & 7.7 & 10.6 & 1.2 & 0.1 \\
\hline 30 & 2.5 & 2.6 & 2.7 & 2.5 & & 3.3 & 4.5 & 24.8 & 6.4 & 9.1 & 0.9 & 0.1 \\
\hline 31 & 2.5 & & 2.7 & 2.5 & & 3.3 & & 42.5 & & 5.1 & 0.9 & \\
\hline SUM & 125.9 & 178.1 & 84.5 & 82.5 & 51.2 & 88.3 & 96.2 & 991.6 & 445.8 & 249.3 & 76.7 & 11.1 \\
\hline
\end{tabular}


TABLE 11. Discharge measurements in outlet stream of Middle Tarn, near South Cascade Glacier

[ $\mathrm{m}^{3} / \mathrm{s}$, cubic meters per second]

\begin{tabular}{cc}
\hline $\begin{array}{c}\text { Stage } \\
\text { (meters) }\end{array}$ & $\begin{array}{c}\text { Discharge } \\
\left(\mathrm{m}^{3} / \mathrm{s}\right)\end{array}$ \\
\hline 0.116 & 0.157 \\
.241 & .432 \\
.274 & .534 \\
.299 & .555 \\
.335 & .657 \\
.363 & 1.001 \\
.479 & 1.671 \\
.497 & 1.648 \\
.561 & 2.278 \\
.588 & 2.549 \\
.587 & 2.421 \\
\hline
\end{tabular}

TABLE 12. Runoff at Middle Tarn Basin, 1993 water year

[Values in millimeters, averaged over the basin; no data indicated by -99.0]

\begin{tabular}{|c|c|c|c|c|c|c|c|c|c|c|c|c|}
\hline DAY & Oct. & Nov. & Dec. & Jan. & Feb. & Mar. & Apr. & May & June & July & Aug. & Sept. \\
\hline 1 & 25.0 & 3.0 & -99.0 & -99.0 & -99.0 & -99.0 & -99.0 & -99.0 & 33.6 & 12.9 & -99.0 & 19.0 \\
\hline 2 & 22.9 & 2.7 & -99.0 & -99.0 & -99.0 & -99.0 & -99.0 & -99.0 & 26.6 & 13.7 & -99.0 & 24.2 \\
\hline 3 & 22.3 & 2.3 & -99.0 & -99.0 & -99.0 & -99.0 & -99.0 & -99.0 & 24.1 & 16.0 & -99.0 & 26.6 \\
\hline 4 & 13.0 & 2.7 & -99.0 & -99.0 & -99.0 & -99.0 & -99.0 & -99.0 & 24.6 & 18.4 & -99.0 & 25.1 \\
\hline 5 & 9.6 & 2.5 & -99.0 & -99.0 & -99.0 & -99.0 & -99.0 & -99.0 & 30.6 & 19.3 & -99.0 & 28.7 \\
\hline 6 & 7.9 & 3.9 & -99.0 & -99.0 & -99.0 & -99.0 & -99.0 & -99.0 & 28.8 & 17.6 & -99.0 & 27.6 \\
\hline 7 & 6.6 & 17.2 & -99.0 & -99.0 & -99.0 & -99.0 & -99.0 & -99.0 & 30.3 & 17.4 & -99.0 & 28.8 \\
\hline 8 & 5.9 & 7.3 & -99.0 & -99.0 & -99.0 & -99.0 & -99.0 & -99.0 & 20.2 & 20.6 & -99.0 & 26.8 \\
\hline 9 & 5.4 & 4.6 & -99.0 & -99.0 & -99.0 & -99.0 & -99.0 & -99.0 & 25.2 & 22.1 & -99.0 & 30.8 \\
\hline 10 & 9.4 & 3.3 & -99.0 & -99.0 & -99.0 & -99.0 & -99.0 & -99.0 & 24.3 & 21.8 & -99.0 & 29.2 \\
\hline 11 & 17.0 & 2.8 & -99.0 & -99.0 & -99.0 & -99.0 & -99.0 & -99.0 & 15.2 & 21.7 & -99.0 & 18.7 \\
\hline 12 & 22.7 & 2.4 & -99.0 & -99.0 & -99.0 & -99.0 & -99.0 & -99.0 & 10.8 & 18.9 & -99.0 & 10.2 \\
\hline 13 & 16.8 & 2.2 & -99.0 & -99.0 & -99.0 & -99.0 & -99.0 & -99.0 & 9.0 & 17.0 & -99.0 & 8.9 \\
\hline 14 & 8.0 & 2.5 & -99.0 & -99.0 & -99.0 & -99.0 & -99.0 & -99.0 & 17.1 & 19.3 & -99.0 & 11.3 \\
\hline 15 & 5.6 & 2.4 & -99.0 & -99.0 & -99.0 & -99.0 & -99.0 & -99.0 & 26.8 & 22.6 & -99.0 & 10.5 \\
\hline 16 & 4.7 & 3.7 & -99.0 & -99.0 & -99.0 & -99.0 & -99.0 & -99.0 & 27.4 & 21.2 & -99.0 & 10.7 \\
\hline 17 & 4.7 & 3.9 & -99.0 & -99.0 & -99.0 & -99.0 & -99.0 & -99.0 & 28.5 & 22.4 & -99.0 & 10.9 \\
\hline 18 & 19.9 & 2.7 & -99.0 & -99.0 & -99.0 & -99.0 & -99.0 & -99.0 & 30.4 & 30.3 & -99.0 & 10.0 \\
\hline 19 & 27.3 & 2.3 & -99.0 & -99.0 & -99.0 & -99.0 & -99.0 & 11.2 & 33.4 & 29.0 & 40.5 & 8.1 \\
\hline 20 & 23.8 & 2.0 & -99.0 & -99.0 & -99.0 & -99.0 & -99.0 & 29.2 & 29.6 & 45.0 & 33.8 & 5.3 \\
\hline 21 & 25.8 & 6.4 & -99.0 & -99.0 & -99.0 & -99.0 & -99.0 & 29.0 & 23.4 & 29.5 & 25.3 & 3.9 \\
\hline 22 & 18.4 & 10.8 & -99.0 & -99.0 & -99.0 & -99.0 & -99.0 & 21.2 & 16.0 & 24.2 & 30.2 & 3.1 \\
\hline 23 & 25.1 & 3.4 & -99.0 & -99.0 & -99.0 & -99.0 & -99.0 & 17.5 & 11.2 & 23.8 & 45.4 & 3.1 \\
\hline 24 & 22.6 & 1.9 & -99.0 & -99.0 & -99.0 & -99.0 & -99.0 & 20.2 & 9.3 & 23.5 & 19.9 & 3.3 \\
\hline 25 & 11.0 & 1.7 & -99.0 & -99.0 & -99.0 & -99.0 & -99.0 & 21.0 & 13.8 & 23.8 & 11.9 & 4.7 \\
\hline 26 & 8.9 & 1.2 & -99.0 & -99.0 & -99.0 & -99.0 & -99.0 & 22.2 & 19.4 & 26.6 & 10.6 & 8.8 \\
\hline 27 & 6.5 & 2.7 & -99.0 & -99.0 & -99.0 & -99.0 & -99.0 & 25.1 & 23.9 & 29.3 & 10.7 & 13.9 \\
\hline 28 & 5.3 & 1.6 & -99.0 & -99.0 & -99.0 & -99.0 & -99.0 & 27.1 & 15.3 & 37.6 & 12.1 & 15.3 \\
\hline 29 & 4.4 & 1.3 & -99.0 & -99.0 & & -99.0 & 99.0 & 29.0 & 12.1 & -99.0 & 13.3 & 18.9 \\
\hline 30 & 3.7 & 8.6 & -99.0 & -99.0 & & -99.0 & -99.0 & 28.0 & 11.7 & -99.0 & 15.5 & 16.9 \\
\hline 31 & 3.2 & & -99.0 & -99.0 & & -99.0 & & 34.9 & & -99.0 & 17.4 & \\
\hline SUM & 413.3 & 115.8 & - & - & - & - & - & - & 652.2 & - & - & 462.9 \\
\hline
\end{tabular}




\section{MASS BALANCE}

The collection of balance measurements made at specific locations at specific times and the recorded temperatures and runoff are used to estimate several area-averaged mass balance values and the dates on which they occur. At South Cascade Glacier, the field measurements are stratigraphic, that is, they are referenced to the time-transgressive surface that formed as the previous ablation season ended. Area-averaged stratigraphic balance values are estimated, as are adjustments to these values, so that the glacier balance values can be related to the water year, October 1, 1992 through September 30, 1993.

Previously published South Cascade Glacier mass balances for the years 1965-67 (Meier and others, 1971; Tangborn and others, 1977) were derived from the same types of data as those used in this report. A major difference between the data sets for 1965-67 and that for 1993 was a denser stake network in the former years--in 1965-67 each stake represented about $0.1 \mathrm{~km}^{2}$ of the glacier surface, and in 1993 each stake represented about $0.5 \mathrm{~km}^{2}$. In both 1965-67 and 1993, the stake networks covered nearly the entire altitude range of the glacier, but the 1965-67 network allowed lateral balance variations to be observed, whereas the 1993 net gave no information about the lateral variations. The 1965-67 area-integrated balance values were derived from maps of balance values. Because there is not sufficient spatial resolution to draw balance maps in 1993, a graphical procedure called the Grid-Index (GI) method is used to create a representation of the area-altitude distribution of a glacier. The GI method is based on gridded surface altitudes (essentially a digital altitude model) and functions of balance variables that are dependent on altitude. The altitude-dependent functions are determined by finding a curve that approximates all the available data. The curve is then evaluated at the altitude of each grid node, and the product of each value and the grid cell area is a balance volume. The cumulative volume is the balance volume, which can be converted to a one-dimensional quantity by division by the number of grid cells. Although the GI method accounts for the area-altitude distribution of the glacier, it does not account for variations of balance values at a given altitude (Krimmel, 1993).

The surface altitude grid used at South Cascade Glacier has a cell size of 0.1 by $0.1 \mathrm{~km}$. The altitude of the entire cell is considered to be the altitude at the nominal center of the cell, which is based on the local X, Y coordinate system; the cell centers are at

$$
\begin{aligned}
X G r i d & =70,170,270 \ldots \\
Y G r i d & =100,200,300 \ldots
\end{aligned}
$$

This particular translation was chosen to allow the entire South Cascade Lake Basin to be included within a 24 - by 40 -grid area.

\section{Winter Snow Balance}

The measured winter snow balance, $\bar{b}_{\mathrm{m}}(\mathrm{s})$, is defined by Mayo and others (1972) as the snow above the previously formed summer surface as measured directly in late spring as near as possible to the time of greatest glacier mass. The snow depth and density measurements made on May 5-6, 1993 are the principal data source for $\bar{b}_{\mathrm{m}}(\mathrm{s})$. The grid used for winter snow balance measurements was based on photographs taken on October 6,1992 . The altitude of each of the 40 probed snow depths was estimated from the 1992 grid (Krimmel, 1993). A second degree polynomial was fit to the snow depth and altitude at the 40 probe points and the snow depth near 
the west end of South Cascade Lake (fig. 13). The snow density at the altitude of each measured snow depth was estimated from the measured density at $1,851 \mathrm{~m}(0.45)$ and the assumption of a density gradient of $0.021 / 100 \mathrm{~m}$ of altitude, which is the same gradient that was measured in April 1992 (Krimmel, 1993). The product of the evaluation of the polynomial (for the snow depth) and the density at the altitude of each grid point gives the snow water equivalent (W.E.) at each grid point. The product of the W.E. at each grid and the grid cell area $\left(0.01 \mathrm{~km}^{2}\right)$ gives the water volume at each cell, and the cumulation of all the cells gives the total water volume of the winter snow, $4.09 \times 10^{6} \mathrm{~m}^{3}$. Dividing this volume by the October 6,1992 grid-cell-area, $2.07 \times 10^{6} \mathrm{~m}^{2}$, gives $\bar{b}_{\mathrm{m}}(\mathrm{s})=1.98 \mathrm{~m}$.

The maximum winter snow balance, $\bar{b}_{\mathrm{w}}(\mathrm{s})$, is defined by Mayo and others (1972) as the maximum of snow mass during the balance year. This quantity is computed or estimated from the measured winter snow balance, $\bar{b}_{\mathrm{m}}(\mathrm{s})$, and from other information that may be available, such as recorded temperature, precipitation, and runoff data. In the spring of 1993 , the date of maximum snow mass was not obvious. The entire snowpack at the pit location was observed to be at $0^{\circ} \mathrm{C}$ on May 5, 1993, indicating that liquid water could flow through the snow. There was a runoff peak from Salix Basin on May 2, but this occurred with an air temperature at about freezing; thus, the rain that caused that peak was probably snow over most of the South Cascade Glacier Basin. The runoff peak from Salix on May 6 may indicate the start of runoff from the South Cascade Glacier Basin, and certainly it had started by May 10 when air temperature was about $10-15^{\circ} \mathrm{C}$. It is estimated that $\bar{b}_{\mathrm{w}}(\mathrm{s})$ was reached on May 10 , and was not significantly greater than $\bar{b}_{\mathrm{m}}(\mathrm{s})$.

\section{Net Mass Balance}

Net balance, $\bar{b}_{\mathrm{n}}$, is defined by Mayo and others (1972) as the change in snow, firn, and ice storage between times, $t_{0}^{\prime}$ and $t_{1}^{\prime}$ of minimum mass. The observation of the balance at each of the stakes (fig. 3, table 3) is the principal data source for $\bar{b}_{\mathrm{n}}$. The stake balances are referenced to the surface formed at the end of the previous ablation season at the stake location. An estimation of the balance change between the last stake measurement and the end of ablation at each stake is made on the basis of the continuously recorded temperatures and stream stages, and in some cases, by measurements of the ice level on the balance stakes in the following balance year. A third degree polynomial is fit to the final estimated balance at three of the four stakes at their respective altitudes and a fourth point, that of the equilibrium line altitude on October 12, 1993, where the balance was zero (fig. 14). Stake 3-93 had an anomolously high snow depth and was excluded from the data set. There is no physical basis for the use of a third polynomial interpolation, but rather it is used only as an empirical fit of the available data so that the GI method can be used. The grid used in the GI method net balance integration is determined from the October 6, 1992 photographs. The polynomial is evaluated at the altitude of each grid cell, and the cumulation of the grid cell volumes, $-2.49 \times 10^{6} \mathrm{~m}^{3}$, divided by the combined area of all the grid cells, $2.03 \times 10^{6} \mathrm{~m}^{2}$, gives $\bar{b}_{\mathrm{n}}=-1.23 \mathrm{~m}$. 


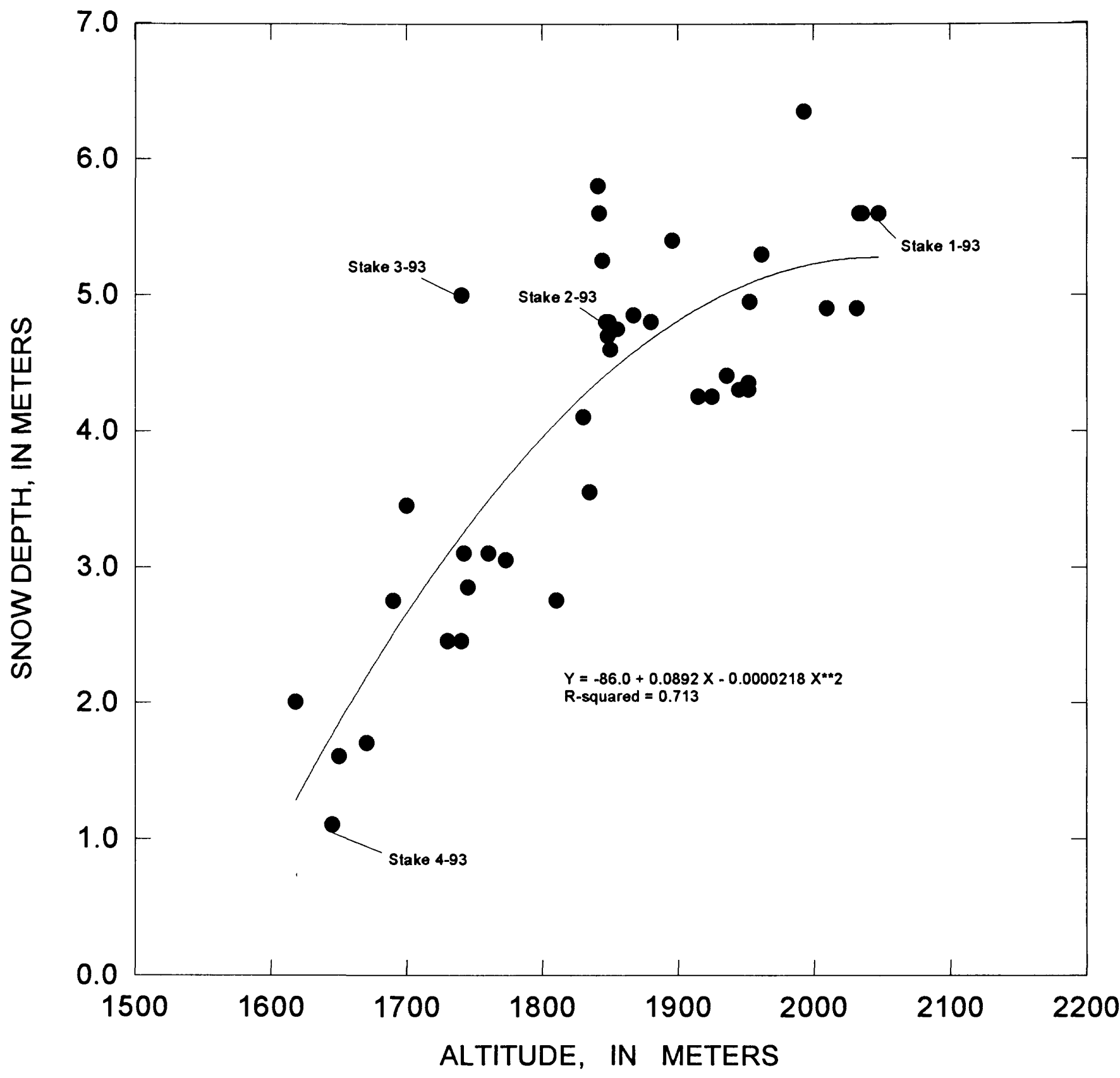

FIGURE 13. South Cascade Glacier snow depth, May 5, 1993, as a function of altitude. 


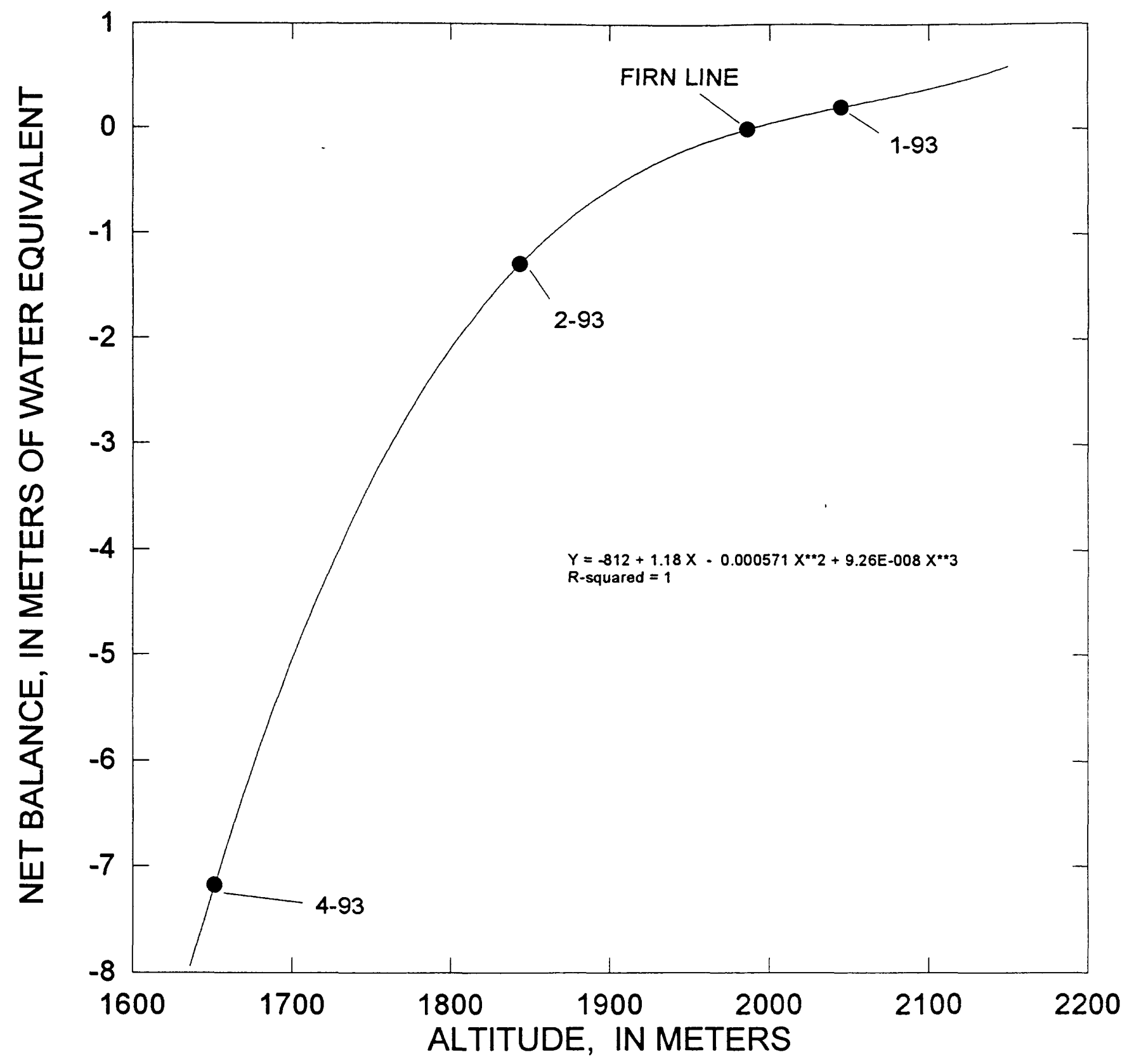

FIGURE 14. Net blance at each South Cascade Glacier 1993 stake. The data point at the zero balance is the equlibrium line. 


\section{Balance Year To Water Year Adjustments}

Mayo and others (1972) define two terms required to relate the stratigraphic measurements to the water year: The initial balance increment, $\bar{b}_{0}$, is the change in balance between the minimum balance near the beginning of the water year and October 1 ; the final balance increment, $\bar{b}_{1}$, is the change in balance between the minimum balance near the end of the water year and September 30 .

The last visit to South Cascade Glacier in the 1992 balance year was on October 10, 1992 at which time there was virtually no new snow on the glacier (Krimmel, 1993). The first visit in the 1993 balance year was on January 31, 1993, at which time probes through the 1993 balance year snow showed $0.17 \mathrm{~m}$ of ice had ablated $(0.15 \mathrm{~m} \mathrm{~W}$.E.) at stake 4-92 after October 10 . The average air temperature remained above freezing until early November 1992. No major periods of precipitation occurred in October or November 1992, but several minor storms probably resulted in mixed rain and snow as late as early November. It is estimated that the glacier was covered with snow and remained so after November 6, 1992, at which time the 1993 balance year began. It is estimated that the initial balance increment $\left(\bar{b}_{0}\right)$, the melt after September 30, 1992, was $-0.05 \mathrm{~m} \mathrm{W.E}$.

The last balance measurements at South Cascade Glacier in the 1993 balance year were on October 12, 1993. During October 1-12, the glacier lost an estimated $0.15 \mathrm{~m}$ of mass. Air temperature remained near or several degrees above freezing until October 31, 1993, and minor ablation occurred on the lower glacier. It is estimated that the final balance increment $\left(\bar{b}_{1}\right)$, the melt after September 30, 1993, was -0.20 m W.E.

The annual balance, $\bar{b}_{\mathrm{a}}$, is defined by Mayo and others (1972) as the change in snow, firn, and ice storage between the beginning and end of some fixed period, which here is the water year. The measured values of $\bar{b}_{0}, \bar{b}_{1}$, and $\bar{b}_{\mathrm{n}}$ at South Cascade Glacier for the 1992 balance year can be used to derive the annual balance, $\bar{b}_{\mathrm{a}}$; where $\bar{b}_{\mathrm{a}}=\bar{b}_{\mathrm{n}}+\bar{b}_{0}-\bar{b}_{1}=-1.08 \mathrm{~m}$.

\section{Balance-Measurement Errors}

Errors in glacier balance measurements are difficult to quantify. In prior years of balance measurements at South Cascade Glacier, error values ranging around $0.10 \mathrm{~m}$ were placed on the balance values (Meier and others, 1971). For 1965 and 1966, more information was used to derive the balances than in 1992 . The availability of less information in 1993 would suggest that greater errors should be assigned to the 1993 balance. This relative paucity of data for 1993 is offset somewhat, however, by the experience gained since the mid-1960's. Estimated errors are: $\bar{b}_{\mathrm{m}}(\mathrm{s}) \pm 0.20 \mathrm{~m}, \bar{b}_{\mathrm{w}}(\mathrm{s}) \pm 0.20 \mathrm{~m}, \bar{b}_{0} \pm 0.05 \mathrm{~m}, \bar{b}_{1} \pm 0.05 \mathrm{~m}, \bar{b}_{\mathrm{n}} \pm 0.20 \mathrm{~m}$, and $\bar{b}_{\mathrm{a}} \pm 0.25 \mathrm{~m}$. Although other factors that affect the balance, such as internal accumulation of ice, superimposed ice, internal melt, and basal melt, are possible, they are not considered in this report. These factors are insignificant compared with the errors assigned to the surface balance values. 


\section{ICE VELOCITY}

Some surface features, usually specific crevasses or debris, are visible on both the October 6, 1992 and the September 1, 1993 vertical photographs. The location of these features was photogrammetrically measured on both dates (table 13), allowing the surface ice velocity to be calculated. The displacements for each measured feature are shown in figure 15, and the value adjacent to the vector is adjusted to an annual velocity, in meters per year. Error in measurements made using this method are those associated with the determination of the location of the features and those associated with the feature identification. The error of the location measurements, based on a least squares adjustment of the available ground control, is estimated to be $0.5 \mathrm{~m}$. In the environment of South Cascade Glacier, where annual ablation may be $8 \mathrm{~m}$, the feature that is observed at the initial and final time for the velocity measurement may be severely influenced by the interim ablation process. It is estimated that the error from this "feature change" process may be as much as $1 \mathrm{~m}$. The combined displacement error, over the 1992-93 measurement period of 0.904 year, is estimated to be $2 \mathrm{~m} / \mathrm{yr}$.

South Cascade Glacier surface velocity was measured during 1957-62 (Meier and Tangborn, 1965). These data are reproduced in figure 15, with the minor modification that in places where multiple measurements were reported in a small area, an average of the values is transcribed onto figure 15 for clarity. The 1957-62 measurements are not exactly equivalent to the 1992-93 measurements. Meier and Tangborn reported annual velocity horizontal components parallel and perpendicular to a curved glacier center line (fig. 15), whereas the 1992-93 reported measurements are horizontal Pythagorean in the local Cartesian coordinate system. Also, in each of the 1957-62 and 1992-93 data sets, no adjustments were made to allow for seasonal or longer term velocity changes. The vector magnitudes over the measurement periods were linearly adjusted to annual magnitudes. In the former data set, periods ranged from slightly less than 2 months to slightly more than 2 years.

It is difficult to make definitive statements concerning changes that have occurred in the glacier surface velocities over the interval between the former and latter measurements for the following reasons: The changes are about the same as the errors in velocity measurements, seasonal variations have not been accounted for, and the spatial gaps in both data sets require that interpolations be made so that the location of the measurements are congruent. After the two data sets are made as similar as possible (the 1992-93 velocities were adjusted to be the component parallel to the 1961 glacier center line) and compared near the 1961 center line, it appears, if anything, that the glacier was flowing at a slightly slower rate in 1992-93 than in 1958-62. In the upper one-third of the glacier, almost no velocity change is evident. In the lower one-third of the glacier, velocity has decreased by about 1 to $2 \mathrm{~m} / \mathrm{yr}$, from about 18 to $16 \mathrm{~m} / \mathrm{yr}$. In the central part of the glacier, velocity has also decreased slightly, remaining about 11 to 12 $\mathrm{m} / \mathrm{yr}$. Between July 9, 1962, and September 9, 1962, the speed of one marker in that area was measured to be more than $15.1 \mathrm{~m} / \mathrm{d}$. This marker was less than $80 \mathrm{~m}$ from a marker that moved at $12.2 \mathrm{~m} / \mathrm{d}$ from October 2, 1959, to October 7, 1961 (Meier and Tangborn, 1965). The anomalously high velocity may have been measured during a seasonal velocity maximum, and erroneously extrapolated to an annual velocity. Near the edges of the lower glacier, the velocity has decreased dramatically in the three-decade period. 
TABLE 13. Positions of velocity features on South Cascade Glacier on October 6, 1992 and September 1, 1993

[Coordinates $\mathrm{X}, \mathrm{Y}$, and $\mathrm{Z}$ are local, in meters]

\begin{tabular}{|c|c|c|c|c|c|c|c|c|c|c|c|}
\hline \multicolumn{3}{|c|}{ Oct. 6, 1992} & \multicolumn{3}{|c|}{ Sept. 1, 1993} & \multicolumn{3}{|c|}{ Oct. 6, 1992} & \multicolumn{3}{|c|}{ Sept. 1, 1993} \\
\hline $\mathrm{X}$ & $\mathrm{Y}$ & $\mathbf{Z}$ & $\mathrm{X}$ & $\mathrm{Y}$ & $\mathrm{Z}$ & $\mathrm{X}$ & $\mathrm{Y}$ & $\mathrm{Z}$ & $\bar{X}$ & $\mathrm{Y}$ & $\mathrm{Z}$ \\
\hline 1830.0 & 3570.4 & 1672.8 & 1833.6 & 3579.1 & 1665.7 & 2053.6 & 2745.2 & 1850.1 & 2054.1 & 2752.3 & 1848.2 \\
\hline 1848.0 & 3433.0 & 1685.7 & 49.4 & 3437.3 & 1682.2 & 53.3 & 2732.9 & 18 & 0.8 & 2741.5 & 185 \\
\hline 1813.5 & 3397.2 & 1699.7 & 16.2 & 3406.1 & 1695.8 & 847.9 & 2705.0 & 1857.8 & 347.9 & 2714.1 & 1856.1 \\
\hline 1701.6 & 3412.9 & 1725.9 & 702.4 & 3429.4 & 1718.7 & 1750.4 & 2663.3 & 1864.9 & 750.0 & 2672.4 & 1863.4 \\
\hline 1723.6 & 3336.5 & 1742.9 & 1726.8 & 3352.8 & 1735.5 & 1855.6 & 2537.1 & 1877.2 & 1854.8 & 2546.7 & 1874.1 \\
\hline 1649.6 & 3276.8 & 1755.9 & 1650.1 & 3293.5 & 1750.6 & 1891.3 & 2610.9 & 1865.4 & 1891.2 & 2620.1 & 1865.0 \\
\hline 1606.9 & 3174.2 & 1790.3 & 1607.2 & 3190.4 & 1783.6 & 1982.2 & 2594.7 & 1867.1 & 1982.4 & 2603.5 & 1865.1 \\
\hline 1534.4 & 3191.0 & 1784.6 & 1535.1 & 3200.2 & 1779.9 & 2074.8 & 2671.3 & 1855.5 & 2075.0 & 2677.9 & 1853.4 \\
\hline 1564.5 & 3091.6 & 1814.6 & 1563.8 & 3103.5 & 1810.4 & 2122.4 & 2649.2 & 1855.9 & 2122.1 & 2653.9 & 1854.5 \\
\hline 1524.6 & 3038.7 & 1826.5 & 1524.5 & 3043.7 & 1825.2 & 2296.7 & 2711.0 & 1862.7 & 2296.7 & 2713.5 & 1861.7 \\
\hline 1719.1 & 3169.6 & 1799.4 & 1717.0 & 3186.4 & 1793.7 & 2286.6 & 2592.6 & 1896.9 & 2287.1 & 2595.7 & 1894.8 \\
\hline 1872.1 & 3161.4 & 1817.9 & 1870.9 & 3172.3 & 1813.9 & 324.5 & 2544.1 & 1913.3 & 2324.3 & 2546.0 & 1912.0 \\
\hline 1888.4 & 3127.2 & 1826.2 & 1888.8 & 3139.9 & 1822.7 & 161.9 & 2528.8 & 1898.4 & 2160.8 & 2534.6 & 1895.3 \\
\hline 1895.9 & 3072.9 & 1833.5 & 1895.2 & 3084.4 & 1831.4 & 177.7 & 2482.0 & 1908.9 & 2177.5 & 2486.0 & 1907.0 \\
\hline 1984.3 & 3150.0 & 1821.2 & 1986.5 & 3159.5 & 1816.7 & 052.5 & 2437.5 & 1906.4 & 2050.7 & 2445.9 & 1902.1 \\
\hline 2170.0 & 3236.2 & 1766.2 & 2170.6 & 3241.8 & 1762.7 & 967.2 & 2437.1 & 1900.9 & 1965.1 & 2446.7 & 1896.7 \\
\hline 2070.6 & 3118.2 & 1823.8 & 2071.8 & 3126.4 & 1819.2 & 819.0 & 2403.1 & 1896.4 & 1815.7 & 2413.4 & 1893.8 \\
\hline 2005.8 & 3041.5 & 1838.2 & 2008.0 & 3051.1 & 1836.7 & 896.7 & 2326.5 & 1914.3 & 1893.2 & 2336.5 & 1910.6 \\
\hline 1912.4 & 3012.3 & 1841.8 & 1912.7 & 3021.9 & 1839.9 & 1992.3 & 2366.5 & 1918.6 & 1990.2 & 2376.7 & 1915.6 \\
\hline 1838.3 & 3007.3 & 1838.7 & 1837.8 & 3018.7 & 1837.2 & 1965.1 & 2290.1 & 1927.0 & 1960.7 & 2299.5 & 1922.8 \\
\hline 1708.0 & 3023.3 & 1830.9 & 1706.1 & 3034.9 & 1824.3 & 2055.0 & 2265.1 & 1935.2 & 2052.2 & 2273.5 & 1932.0 \\
\hline 1605.7 & 3017.8 & 1829.7 & 1604.5 & 3028.7 & 1826.0 & 2100.1 & 2344.8 & 1926.4 & 2098.6 & 2352.2 & 1923.1 \\
\hline 1609.3 & 2941.2 & 1841.6 & 1608.9 & 2950.6 & 1838.3 & 255.2 & 2301.6 & 1943.0 & 2254.8 & 2303.8 & 1941.5 \\
\hline 1644.9 & 2876.2 & 1849.5 & 1644.4 & 2885.5 & 1846.9 & 2289.2 & 2395.9 & 1936.9 & 2288.9 & 2397.4 & 1935.6 \\
\hline 1736.0 & 2909.2 & 1844.7 & 1735.6 & 2919.0 & 1842.8 & 2372.6 & 2434.5 & 1940.7 & 2372.6 & 2435.6 & 1939.2 \\
\hline 1813.7 & 2869.0 & 1848.1 & 1814.3 & 2878.6 & 1847.2 & 317.7 & 1911.9 & 1985.0 & 2315.5 & 1916.3 & 1982.5 \\
\hline 1732.6 & 2977.2 & 1837.0 & 1732.5 & 2989.0 & 1835.6 & 2446.4 & 1794.8 & 2028.5 & 2445.2 & 1801.2 & 2026.8 \\
\hline 1638.6 & 2791.8 & 1854.6 & 1638.2 & 2799.9 & 1853.5 & 297.5 & 1743.1 & 2015.0 & 2293.8 & 1749.5 & 2012.8 \\
\hline 1773.1 & 2774.8 & 1854.9 & 1773.5 & 2783.9 & 1853.1 & 322.1 & 1696.0 & 2019.7 & 2318.0 & 1699.9 & 2018.5 \\
\hline 1938.1 & 2928.3 & 184 & 1940.4 & 2937.9 & 184 & 2304.9 & 2253.4 & 1948.5 & 2305.1 & 2254.7 & 1947.6 \\
\hline 2130.1 & 3041.8 & 1830.4 & 132.3 & 3047.5 & 1828.4 & 2212.9 & 2148.9 & 1952.4 & 2212.3 & 2154.4 & 1950.3 \\
\hline 2144.3 & 2980.3 & 1838.3 & 145.0 & 2984.9 & 1836.5 & 915.0 & 3321.3 & 1737.0 & 1913.3 & 3328.0 & 1731.2 \\
\hline 2246.6 & 3010.0 & 1834.7 & 47.5 & 3012.3 & 1833.7 & 1840.8 & 3121.0 & 1822.9 & 1839.4 & 3133.5 & 1821.2 \\
\hline 2213.7 & 2878.6 & 1842.3 & 2214.7 & 2881.7 & 1840.8 & 1794.9 & 3096.5 & 1826.1 & 1791.8 & 3109.3 & 1820.6 \\
\hline 2075.2 & 2862.9 & 1844.9 & 2075.8 & 2868.2 & 1844.5 & 1754.1 & 3149.7 & 1810.5 & 1751.5 & 3165.7 & 1805.5 \\
\hline 2344.1 & 2859.9 & 1844.8 & 2342.8 & 2860.8 & 1844.8 & 1975.1 & 3210.4 & 1799.6 & 1976.2 & 3220.1 & 1793.8 \\
\hline 2221.7 & 2798.0 & 1842.5 & 2222.2 & 2800.8 & 1840.6 & 1490.8 & 3357.1 & 1745.4 & 1493.7 & 3358.4 & 1742.6 \\
\hline
\end{tabular}




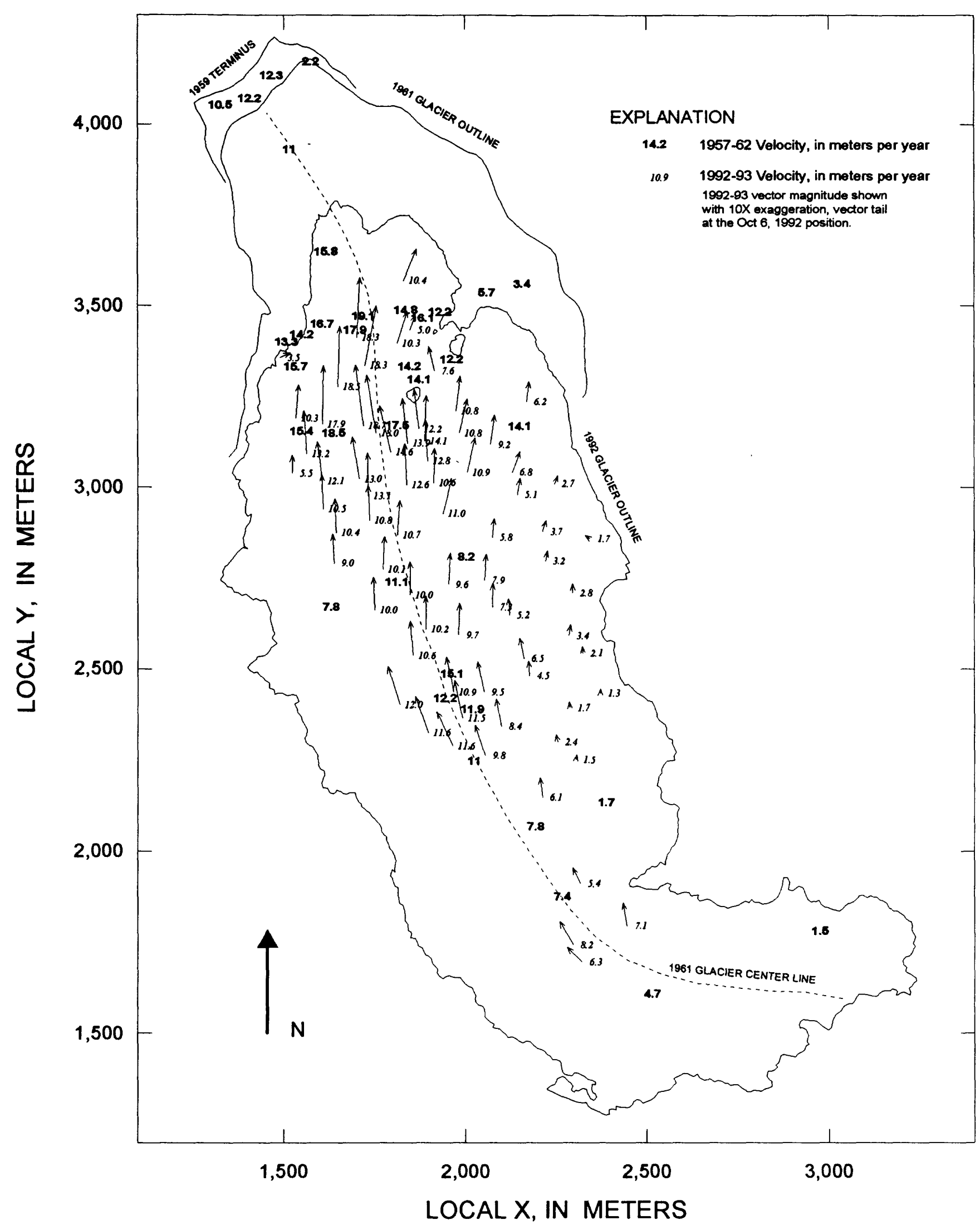

FIGURE 15. Surface velocity of South Cascade Glacier in 1957-62 and 1992-93. 


\section{SUMMARY AND CONCLUSIONS}

Numerous variables related to the glacier regime have been measured on and near South Cascade Glacier, Wash., since the late 1950's. Winter snow accumulation and summer snow, firn, and ice ablation were measured at the glacier to determine the 1993 mass balance.

The net balance in 1993 was $-1.23 \mathrm{~m}$, about average for the period 1977-93 (fig. 16). This was not as negative as would have been expected from observation of the winter balance alone, which was considerably below the average winter balance for a respective period. The low winter balance (which by itself would have resulted in an extremely negative net balance) was compensated by a low magnitude summer balance [summer balance $\left.=\bar{b}_{\mathrm{n}}-\bar{b}_{\mathrm{w}}(\mathrm{s})\right]$. In 1993, there was both less than normal winter accumulation and summer ablation.

Are any climatic trends or changes seen in the 1959-93 South Cascade Glacier mass balance record? Considering the winter balance, there may be a shift toward less winter accumulation beginning in 1977. There is not, however, a simultaneous change in summer balance; thus it appears that it is the reduced winter balance that has resulted in a shift toward more negative net balance values beginning in 1977. A shift in the time series of other environmental variables was also evident in 1976-77. Ebbesmeyer and others (1991) found 40 environmental changes in 197677 , including ice accumulation on a high altitude South American ice cap, and snow depth at Mt. Rainier, Wash. 


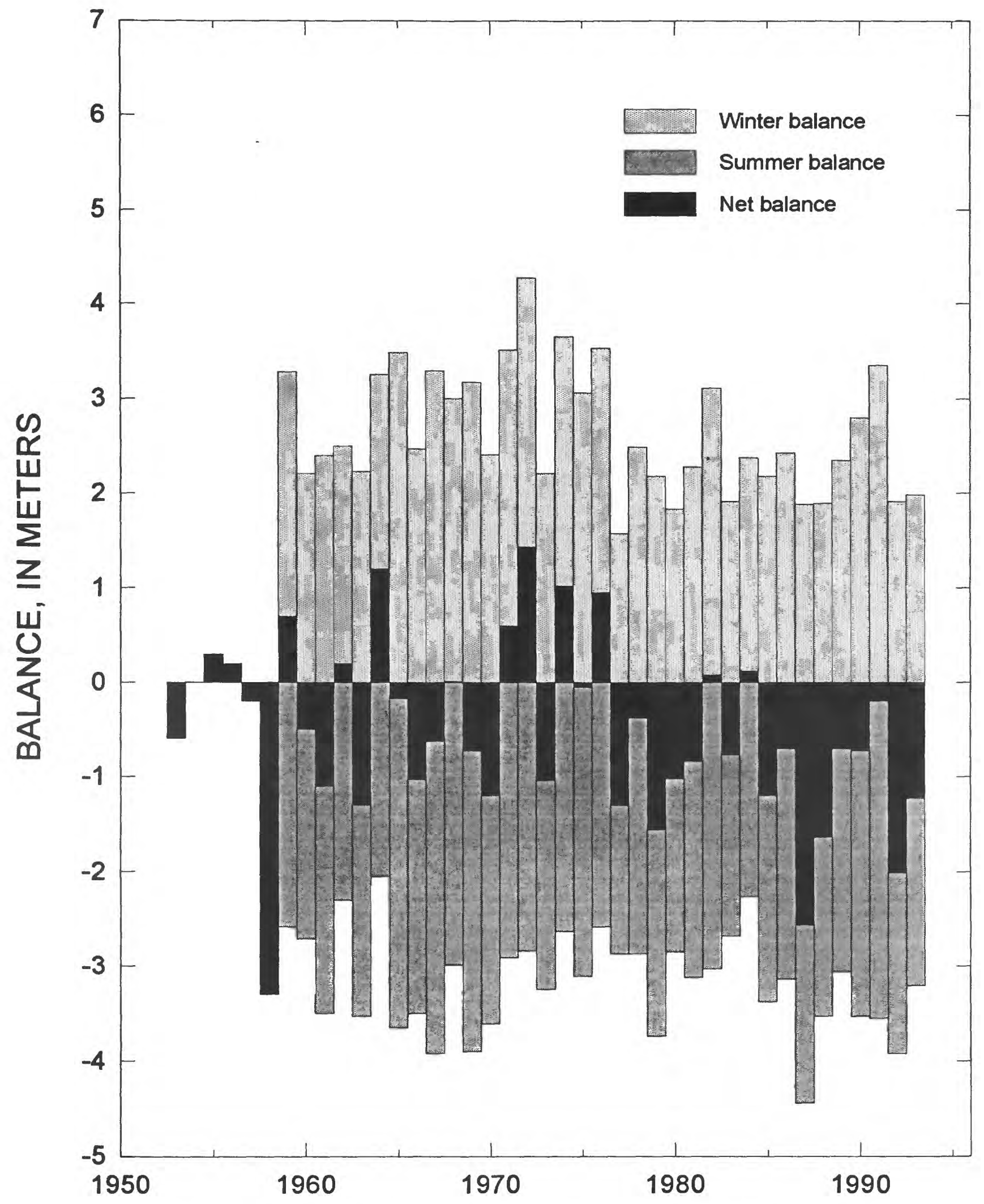

FIGURE 16. Winter, summer, and net mass balances for South Cascade Glacier, 1953-93. Data from Meier and Tangborn (1965) and Krimmel (1993). 


\section{REFERENCES CITED}

Ebbesmeyer, C.C., Cayan, D.R., McLain, D.R., Nichols, F.H., Peterson, D.H., and Redmond, K.T., 1991, 1976 step in the Pacific climate: Forty environmental changes between 19681975 and 1977-1984, in Betancourt, J.L., and Tharp, V.L., eds., Proceedings of the Seventh Annual Pacific Climate (PACLIM) Workshop, April 1990: Calif. Dept. of Water Resources, Interagency Ecological Studies Program Technical Report 26, p. 129-141.

Krimmel, R.M., 1989, Mass balance and volume of South Cascade Glacier, Washington, 1958-1985, in Oerlemans, J., ed., Glacier fluctuations and climatic change: Dordrecht, Netherlands, Kluwer Academic Publishers, p. 193-206.

Krimmel, R.M., 1993, Mass balance, meteorological, and runoff measurements at South Cascade Glacier, Washington, 1992 balance year: U.S. Geological Survey Open-File Report 93-640, $38 \mathrm{p}$.

Mayo, L.R., Meier, M.F., and Tangborn, W.V., 1972, A system to combine stratigraphic and annual mass-balance systems: A contribution to the International Hydrological Decade: Journal of Glaciology, v. 11, no. 61, p. 3-14.

Meier, M.F., and Tangborn, W.V., 1965, Net budget and flow of South Cascade Glacier, Washington: Journal of Glaciology, v. 5, no. 41, p. 547-566.

Meier, M.F., Tangborn, W.V., Mayo, L.R., and Post, Austin, 1971, Combined ice and water balances of Gulkana and Wolverine Glaciers, Alaska, and South Cascade Glacier, Washington, 1965 and 1966 water years: U.S. Geological Survey Professional Paper 715-A, $23 \mathrm{p}$.

Østrem, G., and Brugman, M., 1991, Glacier mass-balance measurements, a manual for field and office work: National Hydrology Research Institute Science Report No. 4, 224 p.

Tangborn, W.V., Krimmel, R.M., and Meier, M.F., 1975, A comparison of glacier mass balance measurements by glaciologic, hydrologic and mapping methods, South Cascade Glacier, Washington: International Association of Hydrological Science, Moscow General Assembly, U.S.S.R., 1971, Proceedings, IAHS-AISH Publication 104, p. 185-196.

Tangborn, W.V., Mayo, L.R., Scully, D.R., and Krimmel, R.M., 1977, Combined ice and water balances of Maclure Glacier, California, South Cascade Glacier, Washington, and Wolverine and Gulkana Glaciers, Alaska, 1967 water year: U.S. Geological Survey Professional Paper 715-B, 20 